\title{
The role of collective action for the emergence and consolidation of democracy
}

\author{
Paolo Li Donni ${ }^{1}$ and Maria Marino ${ }^{2 *}$ (D) \\ ${ }^{1}$ Department of Economics, Business and Statistics, University of Palermo, Palermo, Italy and ${ }^{2}$ Department of Economics \\ and Management (DISEI), University of Florence, Florence, Italy \\ ${ }^{\star}$ Corresponding author. Email: maria.marino@unifi.it
}

(Received 29 July 2019; revised 27 April 2020; accepted 29 April 2020; first published online 16 June 2020)

\begin{abstract}
The role of citizens' collective action for the emergence and consolidation of democracy is generally analysed within bottom-up theories. However, top-down theories show that elites might impede or promote both democracy and collective action through a set of strategies which are often unobserved and vary over time. Democratic persistence and change require then to be assessed in a dynamic framework which considers both citizens and elites' strategies. For such reason, on a large sample of countries in the period 1971-2014, we jointly estimate the probability of collective action and democracy using a Structural Dynamic Model. This allows us to account for the dynamic nature of the two political phenomena under investigation by controlling for their persistence, for initial conditions and time-varying unobserved heterogeneity. We find that collective action matters for the emergence of democracy but not for its consolidation which seems to be related to more structural economic factors.
\end{abstract}

Key words: Collective action; Democracy; Elites

JEL Classification: D70; D74; P16; P47

\section{Introduction}

There is a growing consensus that institutions matter to explain countries' differences in economic performances (see e.g. North, 1991; Tylecote, 2016). In particular, democracy is a powerful predictor of countries' prosperity (e.g. Acemoglu et al., 2019; Alfonso-Gil et al., 2014).

Such findings have resurfaced the question of how democracy emerges and consolidates, in spite of institutional persistence (Acemoglu and Robinson, 2006). Bringing back the theory of collective action into models of democratic change (Acemoglu and Robinson, 2006; Olson, 1965; Ostrom, 2005), some scholars claim that when citizens achieve solving their collective action problem, they might force the elites to democratize and make coups easier to resist, more costly to undertake and less likely to succeed (Acemoglu and Robinson, 2001, 2005; Boix, 2003).

The increase of public demonstrations, from the end of World War II to the more recent global protest wave, has revived these bottom-up theories and the debate about whether citizens' contribution to regime change and democratic stability matters or not. Using the level of protests as a proxy of collective action, several scholars find that citizens contribute positively to democratic change (e.g. Aidt and Franck, 2015; Aidt and Leon, 2016; Aleman and Yang, 2011; Teorell, 2010).

Such bottom-up theories challenge top-down approaches, which consider the elites the most influential agents of democratic change (e.g. Jack and Lagunoff, 2006; Lizzeri and Persico, 2004). Nevertheless, some scholars argue that the dichotomy between top-down and bottom-up theories is misleading because elites and citizens interact strategically. This happens not only through the

(c) Millennium Economics Ltd 2020. This is an Open Access article, distributed under the terms of the Creative Commons Attribution licence (http://creativecommons.org/licenses/by/4.0/), which permits unrestricted re-use, distribution, and reproduction in any medium, provided the original work is properly cited. 
mechanism of expectations, but also because agents have inter-dependent strategies. For instance, pro-democracy elites may help citizens solve their collective action problem by threatening a revolution against the pro-autocracy elites (Ghosal and Proto, 2009; O'Donnell and Schmitter, 1986).

Despite their interdependencies, the bottom-up and top-down theories of democratic change have rarely been tested simultaneously even if elites' behaviours might influence both democratic change and collective action. A possible explanation is that elites' strategies are often unobservable and change over time. While most scholars address the presence of unobserved heterogeneity by using fixed- or random-effects regression and/or instrumental variables, Marino et al. (2020) have recently provided an alternative empirical strategy, which takes into account unobservable factors by using a latent variable and by jointly modelling top-down and bottom-up theories. In such a way, they overcome the critical challenge of finding proper instruments in a cross-country framework. ${ }^{1}$

The strategy elaborated by Marino et al. (2020), however, leaves unexplored whether collective action is still an important driver of democratic change once the dynamic nature of institutional change is considered. For this reason, our work explicitly models the dynamics of collective action, democratic change and unobservable factors. We achieve this aim by estimating a Structural Dynamic Model (SDM), which jointly models the probability of citizens to engage in some form of collective action and the probability of elites to democratize and consolidate the democratic system. We allow these probabilities to depend on previous conditions to model the persistence of collective action and democracy. Moreover, we account for the possibility that elites might impede or promote both democracy and collective action in unobservable ways. To capture all sources of unobserved heterogeneity (time-constant and time-varying), we introduce a latent variable following a first-order Markov chain. The spirit of the latent variable is to decompose countries' unobserved heterogeneity in a discrete number of states which are allowed to change over time, giving the opportunity to disentangle persistence, change and dependence on initial conditions.

We apply the model to 170 countries from 1971 to 2014 and our results find the role of citizens' collective action important for democratic change, but not for democratic consolidation. Such findings stress the relevance of modelling the interaction between citizens and elites, the dynamic nature of the two political phenomena under investigation and unobservable factors.

The paper is organized as follows. Section 2 describes theories of democratic change and the difficulties of testing the role of citizens' collective action on democracy. Section 3 shows the challenges posed by time-varying unobserved heterogeneity and outlines a strategy to address it. Section 4 introduces the data. Section 5 displays the results of our empirical estimation with the presentation of the main findings and some robustness tests. Some conclusions and suggestions for further studies bring the paper to a close in Section 6.

\section{Background}

When studying democratic change, one generally refers to the unseating of the dictatorship through elections (the emergence of democracy) and the subsequent long-lasting status of the democratic rule (democratic consolidation) (O'Donnell and Schmitter, 1986). In such a framework, the focus is on the implementation of new formal rules in a country, in particular constitutional rules (Ostrom, 2005).

Democratic change has historically been considered as a function of structural socio-economic variables (Boix, 2003; Lipset, 1959; Przeworski et al., 2000). More recently, it is analysed within agentbased models that consider transitions as a function both of structural factors and of the behaviours of two main political agents, citizens (bottom-up approach) and elites (top-down approach).

The bottom-up approach sees elites and citizens as having conflicting political preferences with the former supporting autocracy and the latter democracy. The emergence of democracy and its consolidation arise because of citizens' capacity to solve their collective action problem by threatening a

\footnotetext{
${ }^{1}$ Searching for good instruments often leads to focus on a single country (Aidt and Franck, 2015), leaving the questions open to what degree certain patterns can be extended from one country to others.
} 
revolution (Acemoglu and Robinson, 2001, 2005). Such theories do not make clear whether democratic change arises because of a latent threat that indirectly pushes the elite to anticipate a democratic transition or because of the real pressure of collective action.

The top-down approach sees elite's political preferences and power distribution as the determinants of the institutional outcome with no role left for citizens who are, at best, manipulated. Two possible elite-led democratization theories have been elaborated. The first assumes that elites openly relinquish power without social conflict because democracy is in their best interest (Jack and Lagunoff, 2006; Lizzeri and Persico, 2004; O'Donnell and Schimtter, 1986). The second departs from the assumption of close-knit elites introducing intra-elite conflict. Some scholars assume that elites split between pro-democracy soft-liners and pro-dictatorship hard-liners. Democratic change is more likely when soft-liners help citizens solve their collective action problem and to contrast hard-liners (Ghosal and Proto, 2009; O’Donnell and Schimtter, 1986). Others instead claim that new elites (politically disenfranchised yet rising economic groups) struggle against ruling elites to obtain credible commitments against expropriation of their income and assets (Ansell and Samuels, 2010).

When analysing democratic change, both the top-down and bottom-up approaches caution us about the role of persistence. To explain why dictatorships do not easily collapse, some scholars stress the role of history (Acemoglu and Robinson, 2006) and path-dependence (Kingston and Caballero, 2009) pointing to the lasting impact of initial and previous conditions of elites' vested interests and of citizens' capacity to solve their collective action problem. Others explain why democratic institutions, once created, are difficult to revert. Democratic stability depends in large measure on structural factors (e.g. economic development), which change agents' incentives and preferences for democracy (Boix, 2003; Epstein et al., 2006; Przeworski et al., 2000).

Starting in the 70s, the increased availability of data allowed scholars to test the two theories above by focusing either on the role of elites or citizens. When analysing the former, the empirical analysis is made difficult by the partially unobserved nature of the elite's behaviours. However, case studies and historical accounts find that many democratic changes are driven by elites (e.g. Ghosal and Proto, 2009; Lizzeri and Persico, 2004; O'Donnell and Schimtter, 1986). When the role of citizens is accounted for, quantitative analyses performed on a larger sample of countries also find a positive contribution of citizens' collective action on democratic change (e.g. Aidt and Franck, 2015; Aidt and Leon, 2016; Aleman and Yang, 2011; Teorell, 2010).

Given that strategic interactions between citizens and elites are possible, testing the two approaches simultaneously is crucial. ${ }^{2}$ However, this is challenging since elites' behaviours influence democracy both directly and indirectly, with a series of unobservable actions (e.g. anticipating a revolution, inciting citizens to rebel, organizing a coup). Unfortunately, a measure of these actions is not easily available, making any empirical appraisal of the role of the elites in the process of democratic change very difficult.

The presence of unobserved heterogeneity and the potential endogeneity that might derive from it has been already acknowledged in the empirical analysis of democratic change. Several strategies have been proposed. For instance, Acemoglu et al. (2008) rely on country fixed effects, which capture only time-constant unobserved heterogeneity. Others have focused on single countries or specific geographical areas using instrumental variables (e.g. Aidt and Franck, 2015; Aidt and Leon, 2016). While the latter is a good identification strategy, it does not allow a generalization of results to cross-country analysis. Moreover, finding instruments is not always an easy task. Recently, Marino et al. (2020) have proposed a different strategy by estimating a system of equations and by introducing a latent variable, which captures both time-constant and time-varying unobserved heterogeneity.

In our work, following the approach proposed by Marino et al. (2020), we build on the existing evidence on the role of citizens' collective action on democratic change by taking more deeply into

\footnotetext{
${ }^{2}$ Concerning the impact of democratization on inequality, Dorsch and Maarek (2019) indeed show that the two approaches are not incompatible.
} 
account the dynamic nature of the two political processes under scrutiny. In particular, we set an SDM which jointly models elites' decision to democratize (and sustain democracy once in place) and citizens' decision to engage in collective action by disentangling unobserved heterogeneity, persistence and initial conditions. From this perspective, our contribution takes into account the coexistence of change and persistence of institutions and, in so doing, fully captures the role of collective action.

\section{Empirical strategy}

We model both the probability of elites to democratize and consolidate and the probability of citizens to engage in collective action. Let $D_{i t}=\{0,1\}$ being a binary indicator of democracy, where $i$ is the country and $t$ the time period, with $i=1, \ldots, N$ and $t=1, \ldots, T_{i}{ }^{3}$ When the country becomes democratic, the index takes value equal to one. Similarly, let $C A_{i t}$ indicating if country $i$ at the time $t$ is experiencing any collective action.

Suppose $H_{i t}$ is an index capturing a mix of unobservable factors (typically referred to as unobserved heterogeneity), which systematically affect democracy and collective action. We do not formally characterize $H_{i t}$, but one can assume that it captures also the unobserved elites' propensity towards democracy and collective action.

In a standard univariate setting where $D$ is the dependent variable and $C A$ the independent variable, the common approach is modelling the unobservable components by including a set of subject-specific parameters that can be treated as random (e.g. Persson and Tabellini, 2009) or fixed (e.g. Acemoglu et al., 2008; Aidt and Leon, 2016). Given the dynamic nature of the democratic process, it would also be important to include the dependent lagged variable among the covariates and estimate dynamic random or fixed-effects non-linear models (Wooldridge, 2005), which are better suited to control for persistence and to avoid the initial conditions problem (Heckman, 1981). ${ }^{4}$

However, the above models ignore the presence of time-varying unobserved heterogeneity, making collective action potentially endogenous and impeding to disentangle true (persistence) from spurious state dependence (related to unobserved heterogeneity). For such reason, we set a bivariate SDM that explicitly considers the presence of time-varying unobserved heterogeneity $H_{i t}$ and represents it by a finite number of discrete groups captured by a latent variable modelled non-parametrically through a vector of time-varying subject-specific parameters. Finally, potential endogeneity is tackled by jointly modelling $D_{i t}$ and $C A_{i t}$ and capturing persistence through the inclusion of $D_{i t-1}$ and $C A_{i t-1}$ among the covariates.

The SDM models $H_{i t}$ in a flexible way by assuming that (i) the subject-specific random parameter $\alpha_{i t}$ follows a first-order homogeneous Markov chain with latent states $U(c)$, for $c=1, \ldots, k$, and (ii) such latent states make $D_{i t}$ and $C A_{i t}$ conditional independent given $D_{i t-1}, C A_{i t-1}$ and a set of exogenous variable $x_{i t-1}$ measuring socio-economic observable structural characteristics. ${ }^{5}$

The latter is a form of local independence assumption and it implies that, given the set of observable covariates, any source of residual association between $D_{i t}$ and $C A_{i t}$ is related to $H_{i t}$.

To better understand what the latent states stand for, suppose that we could approximate $H_{i t}$ with a discrete random variable, $U$, with support in $\{1,2, \ldots, c\}$. Different states $c$ are simply meant to capture unobserved heterogeneity affecting $C A$ and $D$ after conditioning on $x_{i t-1}$, $C A_{i t-1}$ and $D_{i t-1}$, without any assumption on the underlying structure; what matters here is

\footnotetext{
${ }^{3}$ Democratic change can also be modelled as a continuous variable, but binary indicators are still a standard practice when scholars aim at capturing the minimal requirements for a country to be considered a democracy (e.g. the implementation of the electoral system) (e.g., Acemoglu et al., 2019; Boix, 2003; Papaioannou and Siourounis, 2008; Przeworski et al., 2000).

${ }^{4}$ The initial conditions problem arises because the dependent variable, measured at the first period, is correlated with the subject-specific parameters.

${ }^{5}$ Markov models are not new in the literature on institutional change (Gleditsch and Ward, 1997).
} 
that a sufficient number of states is used to capture all sources of heterogeneity. Since $U$ jointly affects $C A$ and $D$, this implies that our model can be written as a system:

$$
\begin{aligned}
& C A_{i t}=1\left(\sum_{c=1}^{k} \alpha_{c a i t}(c) U_{i t}(c)+x_{i t-1}^{\prime} \beta_{c a}+\gamma_{c a} C A_{i t-1}+\delta_{c a} D_{i t-1}+v_{c a i t}>0\right) \\
& D_{i t}=1\left(\sum_{c=1}^{k} \alpha_{d i t}(c) U_{i t}(c)+x_{i t-1}^{\prime} \beta_{d}+\gamma_{d} C A_{i t-1}+\delta_{d} D_{i t-1}+v_{d i t}>0\right)
\end{aligned}
$$

where $U_{i t}(c)$ denotes a set of $k$ mutually exclusive dummy variables defining latent states membership in each time period; the parameters $\alpha_{i t}$ capture the relative contribution of unobserved heterogeneity. The dynamic nature of the process is captured by $\gamma$ and $\delta$ - the lagged effects of $C A$ and $D$ - which describe persistence $\left(\gamma_{c a}, \delta_{d}\right)$ and processes' crossed effects $\left(\delta_{c a}, \gamma_{d}\right)$. Moreover, the system of equations (1) allows to evaluate the effect of collective action and covariates on democratic consolidation (Boix, 2003). This is achieved by including in the vector of covariates both the interaction between $x_{i t-1}$ and $D_{i t-1}$ and between $C A_{i t-1}$ and $D_{i t-1}$.

Finally, $\left(v_{\text {cait }}, v_{\text {dit }}\right)$ are the error terms with standard logistic distribution. They are usually assumed independent since the latent process makes $D$ and $C A$ conditional independent. Since this assumption may not be always fully satisfied, we relax it by allowing $D_{i t}$ and $C A_{i t}$ being residual correlated conditional on latent states (Li Donni and Thomas, 2019). For this reason, we also include a parameter $\rho$ capturing potential residual association which still remains after conditioning on $x_{t-1}, D_{i t-1}, C A_{i t-1}$ and unobservable states $\alpha(c)$.

Our proposed model above is displayed in Figure $1 .^{6}$

The system of equations (1) is usually completed by (i) a set of transition probabilities describing how countries move between unobserved states, and (ii) the initial probabilities describing how the pattern of latent states depends on the initial level of democracy, collective action and the other covariates.

The choice of the appropriate number of latent states is generally done through the Bayesian information criterion (BIC) by choosing the model with the lowest BIC. More details on the parameterization of the joint distribution and the estimation procedure are reported in the Appendix A.

\section{Data}

Appendix B shows the list of the 170 countries included in our sample, ranging from 1970 to 2014 for a total of 6,719 observations. ${ }^{7}$ We consider the classification of regimes elaborated by Papaioannou and Siourounis (2008) and Acemoglu et al. (2019): they define a binary index (dictatorship/democracy) using an algorithm that combines information from the Freedom House and the Polity IV. In particular, a country is a democracy when the Freedom House scores 'Free', or 'Partially Free' and the Polity IV is positive. ${ }^{8}$ Of the 6,719 observations, we have 118 democratizations and 59 authoritarian reversals.

Citizens' collective action is generally proxied by the level of protests. We take data from the CNTS (Cross-National Time-Series) Data Archive (Banks and Wilson, 2016) ${ }^{9}$ and use the raw number of

\footnotetext{
${ }^{6}$ Dotted lines between $C A$ and $D$ depict the residual association parameter $\rho$.

${ }^{7}$ We focus only on the interval 1971-2014 because the presence of a Markov chain does not allow for missing values in the data. Nevertheless, when observations are missing, we use standard method of linear interpolation.

${ }^{8}$ When the Polity or the Freedom House are not available, Papaioannou and Siourounis (2008) and Acemoglu et al. (2019) employ two additional indicators elaborated by Cheibub et al. (2010) and Boix et al. (2013). Uncertain cases are coded using historical sources. Since the indicator elaborated by Papaioannou and Siourounis (2008) and Acemoglu et al. (2019) is available till 2010, we extend it up to 2014.

${ }^{9}$ Despite CNTS data are created from news reports, they have been widely used in literature (e.g. Passarelli and Tabellini, 2017; Teorell, 2010).
} 


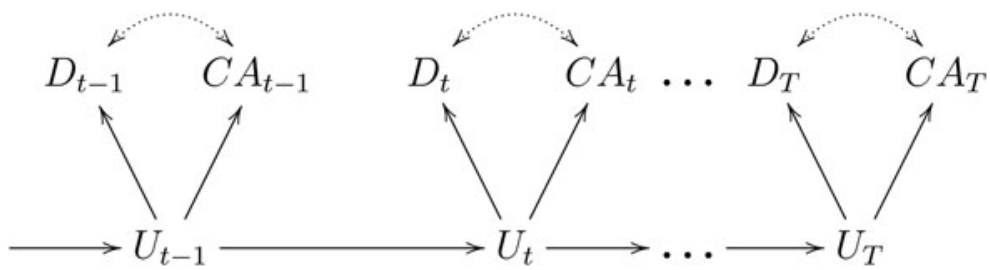

Figure 1. Latent Markov model.

anti-government demonstrations, strikes, riots and revolutions to create a binary index taking value 1 if there is at least one of these collective actions in the country. ${ }^{10}$

We consider four model specifications where covariates are added incrementally. Model E consists of three economic variables: economic development, economic crisis and the presence of natural resources. We proxy economic development by the logarithm of the gross domestic product (GDP) per capita at current prices in US dollar (UN Statistic, 2016). Economic crisis is proxied by an indicator taking value 1 if there is at least one of the following shocks: economic recession, bank, currency and debt crisis. Economic recession is built as a binary index taking value 1 when the level of GDP growth per capita goes below zero. The bank, currency and debt crisis indexes are elaborated by Laeven and Valencia (2018). Finally, to proxy the extent of natural resources, we include the level of oil production collected by Ross and Mahdavi (2015).

Model ES adds education and urbanization to Model E. The first is taken from the Global Educational Attainment Dataset of the Institute for Health Metrics and Evaluation (IHME, 2015). The education variable is built as the average years of education of male and female (15-24 years). Urbanization is taken from the World Development Indicators (World Bank Group, 2012) and refers to the percentage of urban population.

Model ESC includes two indicators of ethnic and religious fractionalization taken from Alesina et al. (2003). They range from 0 (most homogeneous) to 1 (most heterogeneous) and capture to what extent a country is diverse in term of racial, linguistic and religious composition.

Finally, Model ESCE adds the extent of external influences to capture diffusion effects (Gleditsch and Ward, 2006; Starr, 1991). This is measured through the level of democracy in the neighbouring countries. We thus include the average number of democratic countries that are in the same region of the examined country. ${ }^{11}$

We also include year dummies to capture time-trends. Table 1 reports the descriptive statistics.

\section{Results}

\subsection{Structural Dynamic Model}

We fit the SDM with different latent states $k$ for each model described in Section 4 . With the exception of Model E, Table 2 shows that two latent states best fit the data: the BIC index takes the lowest value when $k=2$ in most of the estimated models.

Table 3 reports the estimated parameters for each model given their respective latent states. In particular, we report the coefficients on the two lagged dependent variables $(\gamma$ and $\delta)$, the covariates $(\beta)$ and the residual association between democracy and collective action $(\rho)$. Because of the inclusion of the interactions between $x_{i t-1}$ and $D_{i t-1}$ and between $C A_{i t-1}$ and $D_{i t-1}$, we report two panels. Columns

\footnotetext{
${ }^{10}$ The raw number of collective actions ranges from 0 to 89 with a mean of 1.51 and more than $60 \%$ of the observations being equal to 0 .

${ }^{11}$ Our region specification is based on the United Nations geoscheme, which divides countries into regional and sub-regional groups. It was devised by the United Nations Statistics Division (UNSD) based on the M49 coding classification.
} 
Table 1. Label of variables and summary statistics

\begin{tabular}{lllllr}
\hline Variable & \multicolumn{1}{c}{ Description } & Mean & Std. Dev. & Min & Max \\
\hline$D$ & 1 if the country is democratic, 0 otherwise & 0.47 & 0.50 & 0 & 1 \\
\hline$C A$ & 1 if country has a collective action, 0 otherwise & 0.39 & 0.49 & 0 & 1 \\
\hline loggdp & log GDPpc & 7.51 & 1.59 & 3.52 & 11.68 \\
\hline crisis & 1 if country has a crisis, 0 otherwise & 0.26 & 0.44 & 0 & 1 \\
\hline oil & Oil production & 0.21 & 0.66 & 0.00 & 6.16 \\
\hline educ & Education & 7.32 & 3.18 & 0.85 & 14.98 \\
\hline urbanpop & Urban Population & 5.07 & 2.37 & 0.30 & 10 \\
\hline ethnicfr & Ethnic fractionalization & 0.52 & 0.27 & 0.00 & 1.45 \\
\hline religfr & Religious fractionalization & 0.44 & 0.25 & 0.00 & 1.37 \\
\hline regdem & Democracy in neighbouring countries & 0.47 & 0.35 & 0.00 & 1 \\
\hline \# of observations & & 6,719 & & \\
\hline
\end{tabular}

Table 2. Model selection

\begin{tabular}{lllll}
\hline Model & $k$ & BIC & lk & \#par \\
\hline$E$ & 1 & $9,024.80$ & $-4,242.77$ & 105 \\
\hline & 2 & $8,568.96$ & $-3,989.17$ & 115 \\
\hline & 3 & $8,543.80$ & $-3,945.77$ & 127 \\
\hline$E S$ & 4 & $8,582.13$ & $-3,928.99$ & 141 \\
\hline & 1 & $9,019.05$ & $-4,219.35$ & 113 \\
\hline ESC & 2 & $8,598.93$ & $-3,978.48$ & 125 \\
\hline & 3 & $8,604.59$ & $-3,945.36$ & 139 \\
\hline & 1 & $9,044.52$ & $-4,211.54$ & 121 \\
\hline & 2 & $8,633.09$ & $-3,969.88$ & 135 \\
\hline & 3 & $8,656.77$ & $-3,940.63$ & 151 \\
\hline & 1 & $9,018.10$ & $-4,188.06$ & 125 \\
\hline & 2 & $8,619.73$ & $-3,950.36$ & 140 \\
\hline
\end{tabular}

CA of Panel A (Panel B) for each model display the coefficients of the covariates on the equation of collective action if the country is a dictatorship (democracy). Similarly, Columns $D$ of Panel A (Panel B) report the coefficients on the equation that describes the emergence of democracy (democratic consolidation).

Three sets of results are presented: persistence and cross effects, the role of covariates and unobserved heterogeneity. ${ }^{12}$ Initial conditions are reported in Appendix C.

\footnotetext{
${ }^{12}$ The $\rho$ in Table 3 is always statistically significant indicating that a model, which ignores for potential local dependence, may affect statistical inference leading to biased estimates or to the identification of spurious states (Li Donni and Thomas, 2019).
} 
Table 3. Structural dynamic model

\begin{tabular}{|c|c|c|c|c|c|c|c|c|}
\hline \multirow[b]{3}{*}{ Covariates } & \multicolumn{6}{|c|}{ Panel A (Autocracy $(C A)$ - Emergence of Democracy $(D)$ ) } & & \\
\hline & \multicolumn{2}{|c|}{ Model E } & \multicolumn{2}{|c|}{ Model ES } & \multicolumn{2}{|c|}{ Model ESC } & \multicolumn{2}{|c|}{ Model ESCE } \\
\hline & $C A$ & $D$ & $C A$ & $D$ & $C A$ & $D$ & $C A$ & $D$ \\
\hline \multirow[t]{2}{*}{$L C A(\gamma)$} & $0.89^{\star \star \star}$ & $1.29^{\star \star \star}$ & $1.09^{\star \star \star}$ & $1.38^{\star \star \star}$ & $1.12^{\star \star \star}$ & $1.42^{\star \star \star}$ & $1.13^{\star \star \star}$ & $1.35^{\star \star \star}$ \\
\hline & $(0.13)$ & $(0.26)$ & $(0.11)$ & $(0.25)$ & $(0.11)$ & $(0.25)$ & $(0.11)$ & $(0.25)$ \\
\hline \multirow[t]{2}{*}{$L D(\delta)$} & 0.36 & $2.62^{\star \star}$ & 0.80 & $3.16^{\star \star}$ & $1.54^{\star \star}$ & 2.19 & $1.55^{\star \star}$ & 2.46 \\
\hline & $(0.61)$ & $(1.06)$ & $(0.59)$ & $(1.33)$ & $(0.74)$ & $(1.54)$ & $(0.71)$ & (1.53) \\
\hline \multirow[t]{2}{*}{ Lloggdp } & -0.10 & $0.17^{\star}$ & $-0.22^{\star \star}$ & 0.09 & $-0.23^{\star \star}$ & 0.11 & $-0.25^{\star \star \star}$ & 0.09 \\
\hline & $(0.07)$ & $(0.09)$ & $(0.09)$ & $(0.14)$ & $(0.09)$ & $(0.14)$ & $(0.09)$ & $(0.14)$ \\
\hline \multirow[t]{2}{*}{ Lcrisis } & 0.16 & -0.07 & 0.13 & -0.046 & 0.14 & -0.01 & 0.14 & 0.00 \\
\hline & $(0.11)$ & $(0.21)$ & $(0.11)$ & $(0.21)$ & $(0.11)$ & $(0.22)$ & $(0.11)$ & $(0.22)$ \\
\hline \multirow[t]{2}{*}{ Loil } & $0.14^{\star}$ & $-0.99^{\star \star \star}$ & $0.24^{\star \star \star}$ & $-0.97^{\star \star \star}$ & $0.25^{\star \star \star}$ & $-1.01^{\star \star \star}$ & $0.26^{\star \star \star}$ & $-0.96^{\star * *}$ \\
\hline & $(0.09)$ & $(0.36)$ & $(0.08)$ & $(0.35)$ & $(0.09)$ & $(0.36)$ & $(0.1)$ & $(0.32)$ \\
\hline \multirow[t]{2}{*}{ Leduc } & & & -0.01 & 0.06 & 0.00 & 0.05 & -0.00 & 0.04 \\
\hline & & & $(0.04)$ & $(0.05)$ & $(0.04)$ & $(0.05)$ & $(0.04)$ & $(0.06)$ \\
\hline \multirow[t]{2}{*}{ Lurbanpop } & & & 0.02 & -0.01 & 0.02 & -0.02 & 0.03 & -0.02 \\
\hline & & & $(0.05)$ & $(0.07)$ & $(0.06)$ & $(0.07)$ & $(0.06)$ & $(0.07)$ \\
\hline \multirow[t]{2}{*}{ Lethnicfr } & & & & & 0.35 & -0.39 & 0.39 & -0.07 \\
\hline & & & & & $(0.38)$ & $(0.43)$ & $(0.36)$ & $(0.43)$ \\
\hline \multirow[t]{2}{*}{ Lreligfr } & & & & & 0.022 & -0.36 & -0.00 & $-0.78^{\star}$ \\
\hline & & & & & $(0.34)$ & $(0.41)$ & $(0.34)$ & $(0.43)$ \\
\hline \multirow[t]{2}{*}{ Lregdem } & & & & & & & $0.68^{\star *}$ & $2.29^{\star \star \star}$ \\
\hline & & & & & & & $(0.32)$ & $(0.45)$ \\
\hline \multirow[t]{2}{*}{ cons } & -0.47 & $-6.08^{\star \star \star}$ & -0.10 & $-5.98^{\star \star \star}$ & -0.55 & $-5.65^{\star \star \star}$ & -0.55 & $-5.83^{\star \star \star}$ \\
\hline & $(0.54)$ & $(0.89)$ & $(0.5)$ & $(0.94)$ & $(0.62)$ & $(0.98)$ & $(0.58)$ & $(0.99)$ \\
\hline
\end{tabular}


Panel B (Democracy (CA) - Democratic consolidation (D))

\begin{tabular}{|c|c|c|c|c|c|c|c|c|}
\hline \multirow[b]{2}{*}{ Covariates } & \multicolumn{2}{|c|}{ Model E } & \multicolumn{2}{|c|}{ Model ES } & \multicolumn{2}{|c|}{ Model ESC } & \multicolumn{2}{|c|}{ Model ESCE } \\
\hline & $C A$ & $D$ & $C A$ & $D$ & $C A$ & $D$ & $C A$ & $D$ \\
\hline \multirow[t]{2}{*}{$L C A(\gamma)$} & $0.44^{\star \star *}$ & -0.07 & $0.70^{\star \star \star}$ & -0.02 & $0.72^{\star \star \star}$ & 0.05 & $0.74^{\star \star \star}$ & 0.06 \\
\hline & $(0.14)$ & $(0.32)$ & $(0.12)$ & $(0.32)$ & $(0.12)$ & $(0.32)$ & $(0.12)$ & $(0.32)$ \\
\hline \multirow[t]{2}{*}{ Lloggdp } & -0.11 & $0.94^{\star \star \star}$ & $-0.51^{\star \star \star}$ & $0.75^{\star \star \star}$ & $-0.55^{\star \star \star}$ & $0.80^{\star \star \star}$ & $-0.55^{\star \star \star}$ & $0.71^{\star \star *}$ \\
\hline & $(0.07)$ & $(0.13)$ & $(0.09)$ & $(0.24)$ & $(0.09)$ & $(0.24)$ & $(0.09)$ & $(0.24)$ \\
\hline \multirow[t]{2}{*}{ Lcrisis } & $0.29^{\star \star}$ & $-0.62^{\star \star}$ & $0.28^{\star \star}$ & $-0.65^{\star \star}$ & $0.28^{\star \star}$ & $-0.65^{\star \star}$ & $0.29^{\star \star}$ & $-0.66^{\star *}$ \\
\hline & $(0.13)$ & $(0.29)$ & $(0.12)$ & $(0.29)$ & $(0.12)$ & $(0.29)$ & $(0.12)$ & $(0.29)$ \\
\hline \multirow[t]{2}{*}{ Loil } & $0.21^{*}$ & -0.35 & $0.48^{\star \star \star}$ & -0.36 & $0.50^{\star \star \star}$ & -0.39 & $0.49^{\star \star \star}$ & -0.50 \\
\hline & $(0.11)$ & $(0.28)$ & $(0.1)$ & $(0.29)$ & $(0.1)$ & $(0.3)$ & $(0.1)$ & $(0.31)$ \\
\hline \multirow[t]{2}{*}{ Leduc } & & & 0.07 & 0.12 & 0.039 & 0.13 & 0.05 & 0.12 \\
\hline & & & $(0.04)$ & $(0.09)$ & $(0.05)$ & $(0.1)$ & $(0.05)$ & $(0.1)$ \\
\hline \multirow[t]{2}{*}{ Lurbanpop } & & & $0.23^{\star \star \star}$ & -0.00 & $0.27^{\star \star \star}$ & -0.04 & $0.26^{\star \star \star}$ & -0.11 \\
\hline & & & $(0.07)$ & $(0.14)$ & $(0.07)$ & $(0.12)$ & $(0.07)$ & $(0.12)$ \\
\hline \multirow[t]{2}{*}{ Lethnicfr } & & & & & -0.51 & 0.49 & -0.47 & 0.77 \\
\hline & & & & & $(0.33)$ & $(0.65)$ & $(0.31)$ & $(0.66)$ \\
\hline \multirow[t]{2}{*}{ Lreligfr } & & & & & 0.28 & 0.16 & 0.23 & -0.02 \\
\hline & & & & & $(0.32)$ & $(0.66)$ & $(0.3)$ & $(0.65)$ \\
\hline \multirow[t]{2}{*}{ Lregdem } & & & & & & & 0.08 & $2.00^{\star \star \star}$ \\
\hline & & & & & & & $(0.29)$ & $(0.64)$ \\
\hline \multirow[t]{2}{*}{$\rho$} & \multicolumn{2}{|c|}{$-0.95^{\star \star \star}$} & \multicolumn{2}{|c|}{$-0.73^{\star \star \star}$} & \multicolumn{2}{|c|}{$-0.69^{\star \star \star}$} & \multicolumn{2}{|c|}{$-0.74^{\star \star \star}$} \\
\hline & \multicolumn{2}{|c|}{$(0.25)$} & \multicolumn{2}{|c|}{$(0.21)$} & \multicolumn{2}{|c|}{$(0.21)$} & \multicolumn{2}{|c|}{$(0.21)$} \\
\hline
\end{tabular}




\subsubsection{Persistence and cross effects}

The $\gamma \mathrm{s}(\delta \mathrm{s})$ represent the lagged values of collective action (democracy) on the equation of collective action (democracy) and on the democracy (collective action), capturing respectively persistence and the role of collective action (democracy) on democratic change (collective action).

We find that collective action is persistent when the country is both a dictatorship (Panel A) and a democracy (Panel B). Citizens who have solved their collective action problem in the previous year are also likely to solve it in subsequent years. Thus, collective action is a learning process (Finkel and Muller, 1998; Rüdig and Karyotis, 2014).

Most importantly for the scope of our work, the results show that collective action predicts the emergence of democracy (Panel A), strengthening similar findings in previous studies (e.g. Aidt and Franck, 2015; Aleman and Yang, 2011; Teorell, 2010). However, our results also indicate that collective action does not affect democratic consolidations (Panel B). To explain a similar result, we can draw insight from Haggard and Kaufman (2016) who emphasize the difference between short-run dynamics of the emergence of democracy and its long-run consolidation. The latter is indeed affected by structural factors that do not operate through the former. Accordingly, citizens' and elites' interactions are more likely to depend on economic factors which shape vested interests in the democratic status quo and a generalized aversion to the uncertainties of the authoritarian rule. As also discussed below, our findings give support to this hypothesis: consolidation is more likely to be directly connected with the state of the economy in a country than with the role of citizens.

Finally, the $\delta$ s represent the lagged values of democracy on the equation of collective action and democracy. The first coefficient shows a positive and significant sign but not in all specifications. Similarly, the second one shows a similar pattern, which is a surprising result compared with previous analyses on the role of institutional inertia (e.g. Acemoglu et al., 2008; Epstein et al., 2006).

\subsubsection{The role of covariates}

Our model allows us to assess the role of covariates simultaneously on collective action and democracy.

Economic factors are among the most important predictors of collective action and democratic change. A decline in the level of economic development increases the probability of collective action both when the country is a dictatorship (Panel A) and a democracy (Panel B). Economic crises exacerbate conflict, but only in democracies. These results take on a similar flavour to previous works pointing to a relation between adverse economic shocks and collective action with the former affecting the cost of the latter (Acemoglu and Robinson, 2001, 2005; Brückner and Ciccone, 2011; Burke and Leigh, 2010). Economic development is not related to the emergence of democracy (Panel A), while it has a positive effect on democratic consolidation (Panel B) (Boix, 2003; Przeworski et al., 2000). Similarly, we find that temporary shocks undermine democratic consolidation (Acemoglu and Robinson, 2005). As already mentioned, the importance of economic factors for democratic consolidation supports Haggard and Kaufman (2016). Finally, countries endowed with natural resources are more likely to solve the collective action problem (both in a dictatorship and in a democracy). Such results confirm that natural resources act like selective incentives fuelling collective action (Collier and Hoeffler, 2004). Moreover, the presence of natural resources only decreases the probability of the emergence of democracy leaving unchanged the probability of consolidation (Ross, 2001).

Among social factors, we find that education has generally no effect on collective action and on democratic change. However, Section 5.2.2 shows that such result is sensitive to the degree of violence involved in collective action. This is in line with previous studies showing that education increases the cost of collective action, especially when peaceful forms of mobilization are available (Collier and Hoeffler, 2004; Thyne, 2006). Urbanization increases the probability of collective action in democracies (Panel B), confirming at least partially that opportunities offered by the modernization process favour the solution of the collective action problem (e.g. Lipset, 1959; Przeworski et al., 2000; Teorell, 2010).

Cultural factors (religious and ethnic fractionalization) weakly explain the dynamics of collective action (either in dictatorship or in a democracy), confirming previous studies (Collier and Hoeffler, 
Table 4. Estimated intercepts and conditional average probabilities

\begin{tabular}{lcc}
\hline Estimated intercepts & & \\
\hline Types & $C A$ & $D$ \\
\hline 1 & -1.34 & -5.90 \\
\hline & $(0.58)$ & $(0.99)$ \\
\hline 2 & 0.93 & -5.70 \\
\hline & $(0.59)$ & $(0.99)$ \\
\hline Conditional average probabilities & & \\
\hline 1 & 0.22 & 0.45 \\
\hline 2 & 0.66 & 0.47 \\
\hline
\end{tabular}

2004). They are also weak to predict the emergence of democracy and its consolidation. In Appendix $\mathrm{C}$, however, we show that diversity matters when initial conditions are taken into account.

Finally, we control for the level of democracy in the neighbouring countries: spillover effects have strong effects both on the emergence of democracy and on democratic consolidations (e.g. Starr, 1991; Teorell, 2010).

\subsubsection{Unobserved heterogeneity}

The SDM provides insights on the underlying unobserved heterogeneity captured by time-varying latent states, which lump together countries whose unobserved factors similarly affect the propensity towards democracy and collective action.

Table 4 reports the two random intercepts $\alpha$ s (one for collective action and one for democracy) for the two latent states of Model ESCE. ${ }^{13}$ To explore in detail what these states stand for, conditional average probabilities are computed: they describe how likely unobserved types are to report a positive outcome of the relevant dependent variables. These probabilities reveal that the two groups of countries have almost the same propensity towards democracy, but differ substantially in their propensity towards collective action. The second group is indeed about three times more likely than the first to engage in collective action. The result reveals that heterogeneity is mainly related to factors affecting the propensity of a country to mobilize.

Following theories on democratic change, and assuming that unobservable factors refer to elites' strategies, the first latent state (with a lower propensity towards collective action) can therefore be associated with democratic transitions achieved through elites' institutional reforms induced by the anticipation of perceived collective actions. The second latent state (with a higher propensity towards collective action) could refer instead to transitions where much disagreement exists among elites who have a greater incentive to sustain citizens' efforts towards collective action.

More information on unobserved heterogeneity can be inferred by looking at how the two latent states evolve over time. Table 5 reports transition probabilities. ${ }^{14}$ Unobserved heterogeneity seems to be relatively persistent. In fact, the off-diagonal elements are substantially smaller, indicating that changes in the unobserved factors exist but have smaller probabilities. Specifically, the probability of moving from the first to the second latent state is about $2 \%$, while the opposite is about 1.7 .

\footnotetext{
${ }^{13}$ Results do not differ substantially for other models.

${ }^{14} \mathrm{We}$ investigated the characteristics of the latent process by testing the hypothesis that the transition matrix is diagonal. The likelihood ratio statistic is equal to 77.4, which leads us to strongly reject the hypothesis. Such testing procedure can be found in Bartolucci and Farcomeni (2009).
} 
Table 5. Transition probabilities

\begin{tabular}{llr}
\hline & \multicolumn{2}{c}{ Latent states } \\
\cline { 2 - 3 } & 1 & 2 \\
\hline 1 & 0.9828 & 0.0172 \\
\hline 2 & 0.0233 & 0.9767 \\
\hline
\end{tabular}

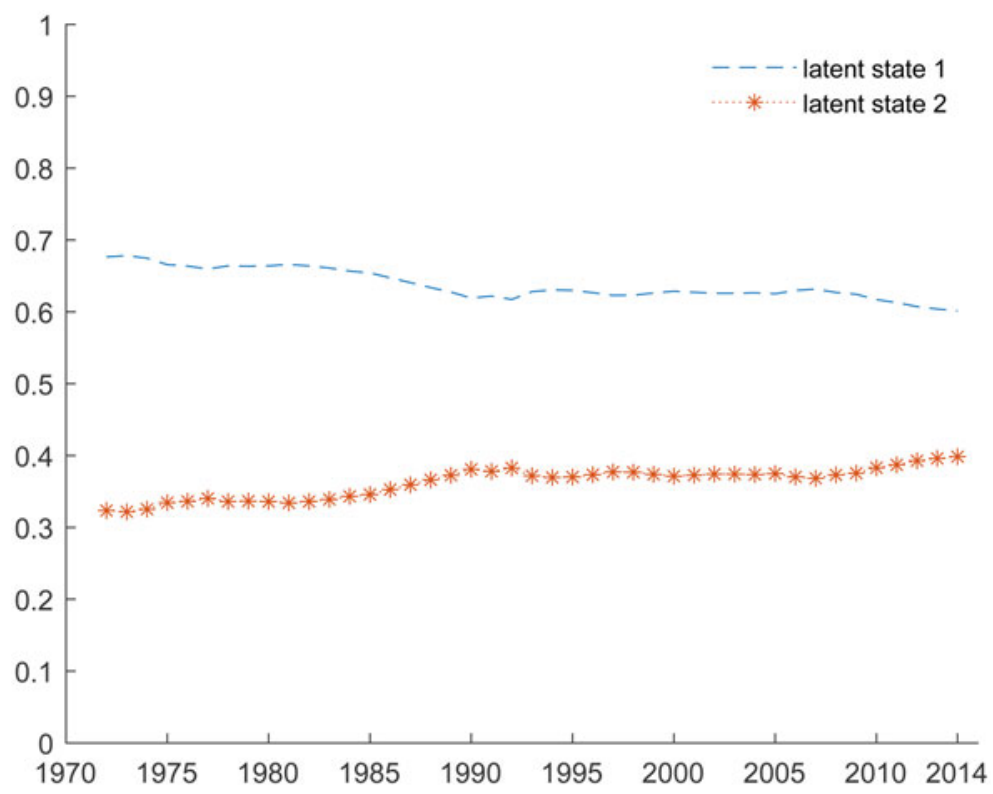

Figure 2. Estimated average probability of each latent state in every year.

The evolution of unobservable factors can be depicted in Figure 2, which plots the average probability of each latent state over time. The probability of the first latent state decreases across time, whereas the second increases.

\subsection{Robustness}

Since models with country/year observations can be highly sensitive to alternative specifications, we run several types of robustness tests. On the one hand, we implement two falsifications tests. On the other hand, we estimate alternative specifications with (i) other indicators of collective action; (ii) other indicators of democracy; and (iii) alternative samples. This is all done on our baseline model (Model ESCE). For the sake of brevity, we report the BIC results of all robustness models and the transition probabilities respectively in Appendix D and E.

\subsubsection{Falsification}

We conduct two falsification tests where the collective action variable is carried forward both 3 ( forward3) and 5 years (forward5). 
Table 6. Falsification tests

\begin{tabular}{|c|c|c|c|c|c|c|c|c|}
\hline \multirow[b]{3}{*}{ Covariates } & \multicolumn{4}{|c|}{ forward3 } & \multicolumn{4}{|c|}{ forward5 } \\
\hline & \multicolumn{2}{|c|}{ Panel A } & \multicolumn{2}{|c|}{ Panel B } & \multicolumn{2}{|c|}{ Panel A } & \multicolumn{2}{|c|}{ Panel B } \\
\hline & $C A$ & $D$ & $C A$ & $D$ & $C A$ & $D$ & $C A$ & $D$ \\
\hline \multirow[t]{2}{*}{$L C A(\gamma)$} & $0.33^{\star \star \star}$ & 0.43 & 0.04 & -0.44 & $0.34^{\star \star \star}$ & 0.10 & 0.18 & $-1.00^{\star \star \star}$ \\
\hline & $(0.13)$ & $(0.28)$ & $(0.14)$ & $(0.33)$ & $(0.13)$ & $(0.25)$ & $(0.14)$ & $(0.32)$ \\
\hline \multirow[t]{2}{*}{$L D(\delta)$} & 0.81 & 1.50 & & & 0.52 & 1.43 & & \\
\hline & $(0.89)$ & $(1.58)$ & & & $(0.92)$ & (1.58) & & \\
\hline \multirow[t]{2}{*}{ Lloggdp } & $-0.33^{\star \star \star}$ & 0.03 & $-0.63^{\star \star \star}$ & $0.78^{\star \star *}$ & $-0.34^{\star \star \star}$ & -0.04 & $-0.59^{\star \star \star}$ & $0.76^{\star \star \star}$ \\
\hline & $(0.11)$ & $(0.15)$ & $(0.11)$ & $(0.24)$ & $(0.12)$ & $(0.15)$ & $(0.12)$ & $(0.24)$ \\
\hline \multirow[t]{2}{*}{ Lcrisis } & 0.12 & 0.06 & $0.23^{\star}$ & $-0.74^{\star \star}$ & 0.11 & 0.09 & $0.26^{\star}$ & $-0.74^{\star \star}$ \\
\hline & $(0.12)$ & $(0.22)$ & $(0.14)$ & $(0.3)$ & $(0.12)$ & $(0.22)$ & $(0.14)$ & $(0.31)$ \\
\hline \multirow[t]{2}{*}{ Loil } & $0.31^{\star \star \star}$ & $-0.96^{\star \star \star}$ & $0.56^{\star \star *}$ & -0.47 & $0.31^{\star \star \star}$ & $-0.85^{\star \star}$ & $0.54^{\star \star \star}$ & -0.42 \\
\hline & $(0.1)$ & $(0.35)$ & $(0.1)$ & $(0.31)$ & $(0.1)$ & $(0.35)$ & $(0.11)$ & $(0.31)$ \\
\hline \multirow[t]{2}{*}{ Leduc } & -0.02 & 0.06 & 0.01 & 0.08 & 0.00 & 0.05 & 0.02 & 0.08 \\
\hline & $(0.05)$ & $(0.06)$ & $(0.06)$ & $(0.1)$ & $(0.05)$ & $(0.06)$ & $(0.06)$ & $(0.1)$ \\
\hline \multirow[t]{2}{*}{ Lurbanpop } & 0.04 & -0.02 & $0.39^{\star \star \star}$ & -0.09 & 0.02 & 0.01 & $0.34^{\star \star \star}$ & -0.06 \\
\hline & $(0.07)$ & $(0.08)$ & $(0.08)$ & $(0.13)$ & $(0.07)$ & $(0.08)$ & $(0.08)$ & $(0.13)$ \\
\hline \multirow[t]{2}{*}{ Lethnicfr } & 0.34 & -0.12 & -0.55 & 0.78 & 0.48 & -0.06 & -0.35 & 0.76 \\
\hline & $(0.37)$ & $(0.45)$ & $(0.39)$ & $(0.7)$ & $(0.37)$ & $(0.46)$ & $(0.43)$ & $(0.71)$ \\
\hline \multirow[t]{2}{*}{ Lreligfr } & 0.13 & $-0.83^{\star}$ & 0.58 & 0.01 & 0.07 & $-0.85^{\star}$ & 0.43 & 0.01 \\
\hline & $(0.32)$ & $(0.46)$ & $(0.39)$ & $(0.68)$ & $(0.32)$ & $(0.47)$ & $(0.41)$ & $(0.69)$ \\
\hline \multirow[t]{2}{*}{ Lregdem } & $0.73^{*}$ & $2.15^{\star \star \star}$ & 0.28 & $2.11^{\star \star \star}$ & $0.79^{\star}$ & $2.34^{\star \star \star}$ & 0.40 & $2.07^{\star \star \star}$ \\
\hline & $(0.44)$ & $(0.47)$ & $(0.36)$ & $(0.67)$ & $(0.43)$ & $(0.49)$ & $(0.41)$ & $(0.68)$ \\
\hline \multirow[t]{2}{*}{ cons } & 0.21 & $-4.98^{\star \star \star}$ & & & 0.30 & $-4.66^{\star \star \star}$ & & \\
\hline & $(0.73)$ & $(0.99)$ & & & $(0.75)$ & $(1.03)$ & & \\
\hline
\end{tabular}


Table 6 shows that the two variables do not display any statistical significant effect. This result alleviates concerns about other possible confounding factors and confirms that 1-year lag of collective actions is not spuriously driving the observed effects of democratic change.

\subsubsection{Robustness on collective action}

Robustness on collective action is done in three ways. First, we account for its intensity and build the binary indicator $C A$ using different thresholds of the raw number of collective actions. In particular, two new indicators are defined taking value 1 if in the country there are at least two (int2) or three (int3) actions. ${ }^{15}$ Results are reported in Table 7. Second, we employ the four indicators of collective action for separate regressions: anti-government demonstrations (antigov), strikes (strikes), riots (riots) and revolutions (revolution). Results are reported in Table 8. Finally, we use the Social Conflict Analysis Database (SCAD) as an alternative source of data for collective action. Information on several forms of social conflict is included from 1990 to 2014. Despite SCAD covers only African countries, it is a high-quality dataset (Aidt and Leon, 2016). ${ }^{16}$ The binary index of collective action ( $\mathrm{scad}$ ) is built by combining three criteria: (1) the type of event must fall in one of the following three categories: organized demonstration, general strikes and violent riots; (2) the target of the event must be the central government; (3) democracy is mentioned as the first source of tension/ disorder. We end up with a total of 1,221 observations (51 countries), 39 democratizations and 19 authoritarian reversals. Table 9 collects the results.

In general, the three above tables confirm the importance of collective action for the emergence of democracy but not for its consolidation. Interestingly, Table 8 unveils which types of collective action are more likely to affect the emergence of democracy. Results show that, while most episodes of collective action increase the likelihood of democratic transitions, strikes behave differently. While this seems to contradict Collier (1999), it confirms Teorell (2010): labour mobilization is not a proximate determinant of the emergence of democracy but precedes other types of collective action.

\subsubsection{Robustness on democracy}

The robustness on democracy is done by employing alternative indicators: the Polity IV, the Freedom House (FH), the binary Boix, Miller and Rosato index (BMR) (2013) and the Score Vector Democracy Indicator (Svmdi) elaborated by Gründler and Krieger (2016).

The Polity captures regime authority spectrum on a 21-point scale ranging from -10 (autocracy) to +10 (consolidated democracy). From it, we define two binary indicators with different thresholds: polity1 takes value 1 if the Polity receives at least a positive value (Acemoglu et al., 2019; Papaioannou and Siourounis, 2008) and polity 6 which takes value 1 if the Polity takes at least a value $\geq$ to 6 (Marshall et al., 2018). The Freedom House (FH) captures a country's political rights and civil liberties from a status of Free, Partly Free or Not Free. Following Papaioannou and Siourounis (2008) and Acemoglu et al. (2019), we create a binary variable taking value 1 when the FH rating is equal to Free and Partly Free $(F H)$. Finally, we split the continuous Score Vector Democracy Indicator (Svmdi) into quartiles and create two dummy variables which take value 1 at the third (svmdi50) and fourth quartile (svmd75), respectively.

Table 10 reports some descriptives of the above six indicators.

Finally, Table 11 reports the results. We find again support for our previous findings: citizens matter for the emergence of democracy but not for its consolidation. An interesting finding emerging from Table 11 is related to democratic persistence. Although it is beyond the scope of our work, such issue would deserve further investigation since democratic persistence seems to be very sensitive to the chosen indicator when time-varying unobserved heterogeneity is taken into account.

\footnotetext{
${ }^{15}$ Countries with one-two-three collective actions represent almost the $90 \%$ of our sample. The mean of int 2 and int 3 are 0.22 and 0.15 , respectively.

${ }^{16}$ An advantage of SCAD over CNTS is that it relies on news from two agencies (the Associated Press and Agence France Presse).
} 
Table 7. Collective action intensity

\begin{tabular}{|c|c|c|c|c|c|c|c|c|}
\hline \multirow[b]{3}{*}{ Covariates } & \multicolumn{4}{|c|}{ int2 } & \multicolumn{4}{|c|}{ int3 } \\
\hline & \multicolumn{2}{|c|}{ Panel A } & \multicolumn{2}{|c|}{ Panel B } & \multicolumn{2}{|c|}{ Panel A } & \multicolumn{2}{|c|}{ Panel B } \\
\hline & $C A$ & $D$ & $C A$ & $D$ & $C A$ & $D$ & $C A$ & $D$ \\
\hline \multirow[t]{2}{*}{$L C A(\gamma)$} & $1.38^{\star \star \star}$ & $1.45^{\star \star \star}$ & $1.06^{\star \star \star}$ & -0.12 & $1.64^{\star \star \star}$ & $1.35^{\star \star \star}$ & $1.08^{\star \star \star}$ & -0.12 \\
\hline & $(0.13)$ & $(0.23)$ & $(0.16)$ & $(0.35)$ & $(0.14)$ & $(0.24)$ & $(0.15)$ & $(0.37)$ \\
\hline \multirow[t]{2}{*}{$L D(\delta)$} & $3.82^{\star \star \star}$ & $2.67^{\star}$ & & & $4.67^{\star \star \star}$ & 2.21 & & \\
\hline & $(0.77)$ & (1.5) & & & $(0.79)$ & (1.49) & & \\
\hline \multirow[t]{2}{*}{ Lloggdp } & 0.04 & 0.14 & $-0.38^{\star \star \star}$ & $0.67^{\star \star \star}$ & -0.03 & 0.10 & $-0.43^{\star \star \star}$ & $0.67^{\star \star \star}$ \\
\hline & $(0.09)$ & $(0.15)$ & $(0.09)$ & $(0.23)$ & $(0.12)$ & $(0.15)$ & $(0.12)$ & $(0.23)$ \\
\hline \multirow[t]{2}{*}{ Lcrisis } & 0.16 & -0.05 & $0.32^{\star *}$ & $-0.65^{\star \star}$ & 0.01 & -0.02 & $0.42^{\star \star \star}$ & $-0.66^{\star \star}$ \\
\hline & $(0.12)$ & $(0.22)$ & $(0.13)$ & $(0.3)$ & $(0.14)$ & $(0.22)$ & $(0.14)$ & $(0.29)$ \\
\hline \multirow[t]{2}{*}{ Loil } & -0.07 & $-1.02^{\star \star \star}$ & 0.11 & -0.51 & $-0.17^{\star}$ & $-0.93^{\star \star \star}$ & -0.00 & -0.51 \\
\hline & $(0.08)$ & $(0.34)$ & $(0.1)$ & $(0.32)$ & $(0.09)$ & $(0.32)$ & $(0.09)$ & $(0.33)$ \\
\hline \multirow[t]{2}{*}{ Leduc } & $0.16^{\star \star \star}$ & 0.04 & 0.12 & 0.14 & $0.30^{\star \star \star}$ & 0.02 & $0.25^{\star \star \star}$ & 0.15 \\
\hline & $(0.05)$ & $(0.06)$ & $(0.08)$ & $(0.1)$ & $(0.05)$ & $(0.06)$ & $(0.06)$ & $(0.1)$ \\
\hline \multirow[t]{2}{*}{ Lurbanpop } & -0.09 & -0.07 & 0.03 & -0.11 & -0.08 & -0.06 & -0.03 & -0.11 \\
\hline & $(0.06)$ & $(0.08)$ & $(0.09)$ & $(0.12)$ & $(0.06)$ & $(0.08)$ & $(0.08)$ & $(0.12)$ \\
\hline \multirow[t]{2}{*}{ Lethnicfr } & $0.69^{\star \star}$ & 0.12 & -0.06 & 0.73 & $0.84^{\star \star \star}$ & 0.00 & -0.53 & 0.68 \\
\hline & $(0.29)$ & $(0.45)$ & $(0.33)$ & $(0.66)$ & $(0.3)$ & $(0.45)$ & $(0.4)$ & $(0.66)$ \\
\hline \multirow[t]{2}{*}{ Lreligfr } & $1.01^{\star \star \star}$ & -0.68 & 0.18 & -0.05 & $1.05^{\star \star \star}$ & $-0.76^{\star}$ & 0.43 & -0.08 \\
\hline & $(0.29)$ & $(0.45)$ & $(0.49)$ & $(0.67)$ & $(0.31)$ & $(0.44)$ & $(0.38)$ & $(0.67)$ \\
\hline \multirow[t]{2}{*}{ Lregdem } & $0.76^{\star \star \star}$ & $2.28^{\star \star \star}$ & -0.02 & $1.93^{\star \star \star}$ & $0.55^{\star}$ & $2.46^{\star \star \star}$ & -0.45 & $1.89^{\star \star \star}$ \\
\hline & $(0.27)$ & $(0.46)$ & $(0.27)$ & $(0.64)$ & $(0.31)$ & $(0.45)$ & $(0.31)$ & $(0.64)$ \\
\hline \multirow[t]{2}{*}{ cons } & $-4.58^{\star \star \star}$ & $-5.71^{\star \star \star}$ & & & $-5.59^{\star \star \star}$ & $-5.24^{\star \star \star}$ & & \\
\hline & $(0.64)$ & $(1.05)$ & & & $(0.67)$ & $(1.03)$ & & \\
\hline
\end{tabular}

${ }^{\star}$ Significant at $10 \%,{ }^{\star \star}$ significant at $5 \%,{ }^{\star \star \star}$ significant at $1 \%$. 


\begin{tabular}{|c|c|c|c|c|c|c|c|c|}
\hline \multirow[b]{3}{*}{ Covariates } & \multicolumn{6}{|c|}{ Panel A (Autocracy $(C A)$ - Emergence of Democracy $(D)$ ) } & & \\
\hline & \multicolumn{2}{|c|}{ antigov } & \multicolumn{2}{|c|}{ strikes } & \multicolumn{2}{|c|}{ riots } & \multicolumn{2}{|c|}{ revolution } \\
\hline & $C A$ & $D$ & $C A$ & $D$ & $C A$ & $D$ & $C A$ & $D$ \\
\hline \multirow[t]{2}{*}{$L C A(\gamma)$} & $0.71^{\star \star *}$ & $0.92^{\star \star \star}$ & $1.25^{\star \star \star}$ & 0.032 & $1.19^{\star \star \star}$ & $1.06^{\star \star \star}$ & $1.40^{\star \star \star}$ & $0.97^{\star \star \star}$ \\
\hline & $(0.14)$ & $(0.24)$ & $(0.25)$ & $(0.39)$ & $(0.14)$ & $(0.24)$ & $(0.16)$ & $(0.28)$ \\
\hline \multirow[t]{2}{*}{$L D(\delta)$} & 0.96 & 1.13 & $3.66^{\star \star \star}$ & 0.85 & $1.99^{\star \star}$ & 1.97 & 1.14 & 2.37 \\
\hline & $(0.81)$ & (1.55) & (1.06) & $(2.06)$ & $(0.78)$ & (1.48) & $(1.06)$ & $(1.47)$ \\
\hline \multirow[t]{2}{*}{ Lloggdp } & -0.13 & 0.08 & 0.20 & 0.12 & -0.02 & 0.07 & $-0.38^{\star \star \star}$ & 0.04 \\
\hline & $(0.11)$ & $(0.16)$ & $(0.16)$ & $(0.29)$ & $(0.1)$ & $(0.15)$ & $(0.12)$ & $(0.14)$ \\
\hline \multirow[t]{2}{*}{ Lcrisis } & 0.13 & -0.01 & 0.32 & -0.15 & -0.07 & -0.00 & 0.15 & 0.01 \\
\hline & $(0.12)$ & $(0.22)$ & $(0.2)$ & $(0.27)$ & $(0.13)$ & $(0.22)$ & $(0.13)$ & $(0.21)$ \\
\hline \multirow[t]{2}{*}{ Loil } & $0.28^{\star \star \star}$ & $-1.02^{\star \star \star}$ & -0.15 & $-0.93^{\star \star \star}$ & $0.31^{\star \star \star}$ & $-0.93^{\star \star \star}$ & $-0.46^{\star \star}$ & $-0.71^{\star \star}$ \\
\hline & $(0.1)$ & $(0.33)$ & $(0.14)$ & $(0.35)$ & $(0.08)$ & $(0.33)$ & $(0.19)$ & $(0.31)$ \\
\hline \multirow[t]{2}{*}{ Leduc } & $0.24^{\star \star \star}$ & 0.06 & 0.08 & $0.29^{\star \star}$ & 0.03 & 0.01 & $-0.14^{\star \star \star}$ & 0.07 \\
\hline & $(0.06)$ & $(0.07)$ & $(0.06)$ & $(0.13)$ & $(0.04)$ & $(0.06)$ & $(0.05)$ & $(0.06)$ \\
\hline \multirow[t]{2}{*}{ Lurbanpop } & -0.03 & -0.07 & $-0.19^{\star \star}$ & $-0.39^{\star \star \star}$ & -0.02 & -0.04 & 0.08 & -0.02 \\
\hline & $(0.06)$ & $(0.08)$ & $(0.08)$ & $(0.14)$ & $(0.06)$ & $(0.08)$ & $(0.06)$ & $(0.07)$ \\
\hline \multirow[t]{2}{*}{ Lethnicfr } & -0.19 & 0.13 & -0.01 & 0.70 & -0.25 & -0.20 & -0.20 & -0.13 \\
\hline & $(0.38)$ & $(0.47)$ & $(0.43)$ & $(0.63)$ & $(0.33)$ & $(0.44)$ & $(0.39)$ & $(0.44)$ \\
\hline \multirow[t]{2}{*}{ Lreligfr } & $-1.09^{\star \star \star}$ & $-1.16^{\star \star}$ & -0.56 & $-2.35^{\star \star \star}$ & $0.77^{\star \star}$ & -0.67 & -0.26 & $-0.79^{\star}$ \\
\hline & $(0.32)$ & $(0.46)$ & $(0.44)$ & $(0.7)$ & $(0.34)$ & $(0.44)$ & $(0.34)$ & $(0.43)$ \\
\hline \multirow[t]{2}{*}{ Lregdem } & $0.63^{*}$ & $2.12^{\star \star \star}$ & $1.07^{\star \star}$ & $5.10^{\star \star \star}$ & 0.36 & $2.41^{\star \star \star}$ & -0.16 & $2.58^{\star \star \star}$ \\
\hline & $(0.36)$ & $(0.47)$ & $(0.52)$ & $(0.86)$ & $(0.35)$ & $(0.45)$ & $(0.42)$ & $(0.44)$ \\
\hline \multirow[t]{2}{*}{ cons } & -0.68 & $-4.50^{\star \star \star}$ & $-4.64^{\star \star \star}$ & $-6.15^{\star \star \star}$ & $-3.02^{\star \star \star}$ & $-5.01^{\star \star \star}$ & -0.28 & $-5.19^{\star \star \star}$ \\
\hline & $(0.73)$ & (1.04) & (0.9) & $(1.82)$ & $(0.65)$ & $(0.97)$ & $(0.79)$ & $(0.97)$ \\
\hline
\end{tabular}


Panel B (Democracy (CA) - Democratic consolidation (D))

\begin{tabular}{|c|c|c|c|c|c|c|c|c|}
\hline \multirow[b]{2}{*}{ Covariates } & \multicolumn{2}{|c|}{ antigov } & \multicolumn{2}{|c|}{ strikes } & \multicolumn{2}{|c|}{ riots } & \multicolumn{2}{|c|}{ revolution } \\
\hline & $C A$ & $D$ & $C A$ & $D$ & $C A$ & $D$ & $C A$ & $D$ \\
\hline \multirow[t]{2}{*}{$L C A(\gamma)$} & $0.63^{\star \star \star}$ & -0.52 & $0.65^{\star \star \star}$ & 0.04 & $1.08^{\star \star \star}$ & -0.23 & $1.72^{\star \star \star}$ & -0.24 \\
\hline & $(0.12)$ & $(0.37)$ & $(0.2)$ & $(0.49)$ & $(0.14)$ & $(0.37)$ & $(0.19)$ & $(0.39)$ \\
\hline \multirow[t]{2}{*}{ Lloggdp } & $-0.3^{\star \star}$ & $0.83^{* * *}$ & $-0.31^{\star \star}$ & $0.69^{\star \star}$ & $-0.19^{*}$ & $0.69^{\star \star \star}$ & $-0.70^{\star \star \star}$ & $0.64^{\star \star *}$ \\
\hline & $(0.13)$ & $(0.24)$ & $(0.14)$ & (0.3) & $(0.11)$ & $(0.23)$ & $(0.15)$ & $(0.24)$ \\
\hline \multirow[t]{2}{*}{ Lcrisis } & $0.34^{\star \star *}$ & $-0.65^{\star \star}$ & $0.28^{*}$ & $-0.69^{\star *}$ & 0.05 & $-0.65^{\star \star}$ & 0.19 & $-0.63^{\star \star}$ \\
\hline & $(0.13)$ & $(0.3)$ & $(0.16)$ & $(0.33)$ & $(0.14)$ & $(0.29)$ & (0.19) & $(0.29)$ \\
\hline \multirow[t]{2}{*}{ Loil } & $0.40^{\star \star \star}$ & -0.51 & -0.10 & -0.54 & $0.40^{\star \star \star}$ & -0.44 & $0.39^{\star \star}$ & -0.47 \\
\hline & $(0.11)$ & $(0.32)$ & $(0.21)$ & $(0.42)$ & $(0.11)$ & $(0.31)$ & $(0.2)$ & $(0.32)$ \\
\hline \multirow[t]{2}{*}{ Leduc } & $0.18^{\star \star \star}$ & 0.15 & 0.04 & $0.29^{\star \star}$ & -0.00 & 0.12 & -0.12 & 0.15 \\
\hline & $(0.06)$ & $(0.1)$ & $(0.07)$ & $(0.13)$ & $(0.05)$ & $(0.1)$ & $(0.08)$ & $(0.1)$ \\
\hline \multirow[t]{2}{*}{ Lurbanpop } & 0.08 & -0.15 & 0.10 & -0.24 & 0.07 & -0.10 & $0.26^{\star \star \star}$ & -0.11 \\
\hline & $(0.07)$ & $(0.12)$ & $(0.07)$ & $(0.16)$ & $(0.06)$ & $(0.12)$ & $(0.09)$ & $(0.12)$ \\
\hline \multirow[t]{2}{*}{ Lethnicfr } & -0.26 & 0.86 & 0.26 & 1.13 & $-1.02^{\star \star \star}$ & 0.53 & -0.35 & 0.74 \\
\hline & $(0.37)$ & $(0.68)$ & $(0.42)$ & $(0.8)$ & $(0.36)$ & $(0.66)$ & $(0.49)$ & $(0.65)$ \\
\hline \multirow[t]{2}{*}{ Lreligfr } & $-0.87^{\star \star}$ & -0.16 & $-1.88^{\star \star \star}$ & -0.76 & $0.66^{\star \star}$ & 0.08 & 0.05 & -0.12 \\
\hline & $(0.37)$ & $(0.68)$ & $(0.45)$ & $(0.77)$ & $(0.32)$ & $(0.66)$ & $(0.54)$ & $(0.64)$ \\
\hline \multirow[t]{2}{*}{ Lregdem } & -0.21 & $1.79^{\star \star \star}$ & 0.43 & $2.40^{\star \star \star}$ & $-0.65^{\star \star}$ & $1.88^{\star \star \star}$ & -0.61 & $1.96^{\star \star \star}$ \\
\hline & $(0.31)$ & (0.65) & $(0.36)$ & $(0.8)$ & $(0.3)$ & $(0.64)$ & $(0.44)$ & $(0.64)$ \\
\hline
\end{tabular}


Table 9. Alternative collective action data (SCAD)

\begin{tabular}{|c|c|c|c|c|}
\hline \multirow[b]{3}{*}{ Covariates } & \multicolumn{4}{|c|}{$S C A D$} \\
\hline & \multicolumn{2}{|c|}{ Panel A } & \multicolumn{2}{|c|}{ Panel B } \\
\hline & $C A$ & $D$ & $C A$ & $D$ \\
\hline \multirow[t]{2}{*}{$L C A(\gamma)$} & 0.39 & $1.04^{\star \star}$ & $0.84^{\star \star}$ & -0.92 \\
\hline & $(0.25)$ & $(0.44)$ & $(0.37)$ & $(0.67)$ \\
\hline \multirow[t]{2}{*}{$\angle D(\delta)$} & -2.93 & 0.08 & & \\
\hline & $(2.54)$ & $(4.05)$ & & \\
\hline \multirow[t]{2}{*}{ Lloggdp } & 0.11 & -0.24 & $0.97^{\star \star}$ & 0.27 \\
\hline & $(0.26)$ & $(0.34)$ & $(0.44)$ & $(0.61)$ \\
\hline \multirow[t]{2}{*}{ Lcrisis } & 0.29 & $-1.01^{\star \star}$ & 0.34 & -0.68 \\
\hline & $(0.25)$ & $(0.43)$ & $(0.37)$ & $(0.56)$ \\
\hline \multirow[t]{2}{*}{ Loil } & -0.34 & 0.00 & $1.05^{\star}$ & 0.57 \\
\hline & $(0.57)$ & $(1.47)$ & $(0.54)$ & (3.41) \\
\hline \multirow[t]{2}{*}{ Leduc } & $0.39^{\star \star *}$ & $-0.44^{\star \star \star}$ & 0.11 & 0.54 \\
\hline & $(0.1)$ & $(0.16)$ & $(0.16)$ & $(0.28)$ \\
\hline \multirow[t]{2}{*}{ Lurbanpop } & -0.06 & $0.45^{\star \star}$ & $-0.70^{\star \star \star}$ & -0.32 \\
\hline & $(0.14)$ & $(0.21)$ & $(0.23)$ & $(0.36)$ \\
\hline \multirow[t]{2}{*}{ Lethnicfr } & $-1.42^{*}$ & $-2.19^{\star}$ & 0.65 & 1.78 \\
\hline & $(0.83)$ & (1.24) & (1.3) & (2.09) \\
\hline \multirow[t]{2}{*}{ Lreligfr } & 0.60 & $1.96^{\star \star}$ & -1.07 & -0.08 \\
\hline & $(0.63)$ & $(0.94)$ & $(1.02)$ & $(1.52)$ \\
\hline \multirow[t]{2}{*}{ Lregdem } & 0.45 & $3.27^{\star \star \star}$ & 0.07 & 2.30 \\
\hline & $(0.57)$ & $(1.24)$ & $(1.38)$ & (2.05) \\
\hline \multirow[t]{2}{*}{ cons } & -2.63 & -0.01 & & \\
\hline & (1.75) & $(2.16)$ & & \\
\hline
\end{tabular}

${ }^{*}$ Significant at $10 \%,{ }^{* \star}$ significant at $5 \%,{ }^{* \star *}$ significant at $1 \%$.

Table 10. Alternative indicators of Democracy

\begin{tabular}{lccccr}
\hline Index & Years & Obs & \#Country & Democratizations & Reversals \\
\hline polity1 & $1973-2014$ & 6,719 & 170 & 116 & 62 \\
\hline polity6 & $1973-2014$ & 6,719 & 170 & 100 & 46 \\
\hline FH & $1973-2014$ & 6,458 & 169 & 134 & 114 \\
\hline BMR & $1971-2014$ & 6,719 & 170 & 83 & 43 \\
\hline svmdi50 & $1971-2014$ & 6,719 & 170 & 136 & 79 \\
\hline svmdi75 & $1971-2014$ & 6,719 & 170 & 119 & 64 \\
\hline
\end{tabular}


Table 11. Democracy

\begin{tabular}{|c|c|c|c|c|c|c|c|c|c|c|c|c|}
\hline \multicolumn{13}{|c|}{ Panel A (Autocracy $(C A)$ - Emergence of democracy $(D)$ ) } \\
\hline \multirow[b]{2}{*}{ Covariates } & \multicolumn{2}{|c|}{ polity1 } & \multicolumn{2}{|c|}{ polity 6} & \multicolumn{2}{|c|}{$\mathrm{FH}$} & \multicolumn{2}{|c|}{$B M R$} & \multicolumn{2}{|c|}{ svmdi50 } & \multicolumn{2}{|c|}{ svmdi75 } \\
\hline & $C A$ & $D$ & $C A$ & $D$ & $C A$ & $D$ & $C A$ & $D$ & $C A$ & $D$ & $C A$ & $D$ \\
\hline \multirow[t]{2}{*}{$L C A(\gamma)$} & $1.04^{\star \star \star}$ & $0.83^{\star \star \star}$ & $1.14^{\star \star \star}$ & $1.16^{\star \star \star}$ & $1.36^{\star \star \star}$ & $1.02^{\star \star \star}$ & $1.03^{\star \star \star}$ & $1.56^{\star \star \star}$ & $1.10^{\star \star \star}$ & $1.13^{\star \star \star}$ & $0.73^{\star \star \star}$ & $0.55^{\star \star}$ \\
\hline & $(0.12)$ & $(0.25)$ & $(0.11)$ & $(0.27)$ & $(0.14)$ & $(0.23)$ & $(0.11)$ & $(0.31)$ & $(0.12)$ & $(0.23)$ & $(0.12)$ & $(0.25)$ \\
\hline \multirow[t]{2}{*}{$L D(\delta)$} & 1.05 & $3.56^{\star \star}$ & 1.07 & $4.04^{\star \star}$ & $2.00^{\star \star \star}$ & $4.46^{\star \star \star}$ & 0.82 & $6.51^{\star \star \star}$ & 1.11 & $6.05^{\star \star \star}$ & $1.44^{\star}$ & $6.32^{\star \star \star}$ \\
\hline & $(0.7)$ & (1.49) & $(0.67)$ & (1.63) & $(0.71)$ & (1.13) & $(0.8)$ & $(1.87)$ & $(0.71)$ & $(1.41)$ & $(0.77)$ & (1.54) \\
\hline \multirow[t]{2}{*}{ Lloggdp } & $-0.18^{\star \star}$ & 0.00 & $-0.26^{\star \star \star}$ & -0.04 & -0.15 & 0.19 & $-0.25^{\star \star \star}$ & $0.31^{\star}$ & $-0.27^{\star \star \star}$ & $0.34^{\star \star}$ & $-0.26^{\star \star}$ & $0.33^{\star}$ \\
\hline & $(0.09)$ & $(0.16)$ & $(0.09)$ & $(0.16)$ & $(0.1)$ & $(0.13)$ & $(0.09)$ & $(0.18)$ & $(0.09)$ & $(0.14)$ & $(0.1)$ & $(0.17)$ \\
\hline \multirow[t]{2}{*}{ Lcrisis } & 0.04 & -0.09 & $0.18^{\star}$ & 0.03 & $0.23^{\star}$ & 0.14 & 0.15 & 0.07 & $0.22^{\star \star}$ & 0.09 & 0.16 & -0.01 \\
\hline & $(0.12)$ & $(0.22)$ & $(0.11)$ & $(0.23)$ & $(0.14)$ & $(0.2)$ & $(0.1)$ & $(0.25)$ & $(0.11)$ & $(0.2)$ & $(0.11)$ & $(0.22)$ \\
\hline \multirow[t]{2}{*}{ Loil } & $0.27^{\star \star \star}$ & -0.28 & $0.28^{\star \star \star}$ & $-0.57^{\star \star}$ & $0.32^{\star \star \star}$ & $-0.63^{\star \star \star}$ & $0.24^{\star \star}$ & $-0.88^{\star \star}$ & $0.27^{\star \star \star}$ & $-0.72^{\star \star}$ & $0.28^{\star \star \star}$ & $-1.20^{\star \star \star}$ \\
\hline & $(0.09)$ & $(0.22)$ & $(0.09)$ & $(0.25)$ & $(0.1)$ & $(0.24)$ & $(0.09)$ & $(0.35)$ & $(0.09)$ & $(0.29)$ & $(0.08)$ & $(0.33)$ \\
\hline \multirow[t]{2}{*}{ Leduc } & -0.01 & -0.03 & -0.01 & 0.08 & 0.07 & -0.04 & -0.03 & 0.10 & -0.04 & 0.05 & $0.13^{\star \star \star}$ & $0.17^{\star \star \star}$ \\
\hline & $(0.05)$ & $(0.06)$ & $(0.06)$ & $(0.06)$ & $(0.06)$ & $(0.06)$ & $(0.05)$ & $(0.07)$ & $(0.04)$ & $(0.05)$ & $(0.04)$ & $(0.06)$ \\
\hline \multirow[t]{2}{*}{ Lurbanpop } & -0.02 & 0.02 & 0.03 & 0.01 & -0.10 & 0.06 & 0.04 & $-0.17^{\star}$ & 0.07 & $-0.19^{\star \star}$ & 0.07 & $-0.16^{\star}$ \\
\hline & $(0.06)$ & $(0.08)$ & $(0.08)$ & $(0.08)$ & $(0.06)$ & $(0.07)$ & $(0.05)$ & $(0.09)$ & $(0.05)$ & $(0.08)$ & $(0.06)$ & $(0.09)$ \\
\hline \multirow[t]{2}{*}{ Lethnicfr } & 0.47 & 0.26 & 0.40 & -0.06 & $1.47^{\star \star \star}$ & 0.22 & -0.04 & 0.26 & 0.23 & $0.67^{\star}$ & 0.34 & 0.22 \\
\hline & $(0.38)$ & $(0.45)$ & $(0.45)$ & $(0.46)$ & $(0.46)$ & $(0.46)$ & $(0.58)$ & $(0.49)$ & $(0.32)$ & $(0.4)$ & $(0.4)$ & $(0.45)$ \\
\hline \multirow[t]{2}{*}{ Lreligfr } & -0.33 & $-0.90^{\star \star}$ & -0.03 & -0.313 & $-0.639^{\star}$ & -0.14 & 0.01 & $-1.10^{\star \star}$ & 0.25 & $-0.73^{\star}$ & -0.45 & $-1.36^{\star \star \star}$ \\
\hline & $(0.35)$ & $(0.44)$ & $(0.35)$ & $(0.45)$ & $(0.38)$ & $(0.39)$ & $(0.34)$ & $(0.5)$ & $(0.32)$ & $(0.4)$ & $(0.38)$ & $(0.46)$ \\
\hline \multirow[t]{2}{*}{ Lregdem } & $0.80^{\star \star}$ & $1.80^{\star \star \star \star}$ & $1.03^{\star \star \star}$ & $2.27^{\star \star \star}$ & $1.05^{\star \star}$ & $1.44^{\star \star \star}$ & $1.12^{\star \star \star}$ & $2.56^{\star \star \star}$ & $0.82^{\star \star}$ & $2.46^{\star \star \star}$ & $0.84^{\star \star}$ & $3.16^{\star \star \star}$ \\
\hline & $(0.4)$ & $(0.5)$ & $(0.32)$ & $(0.46)$ & $(0.45)$ & $(0.48)$ & $(0.3)$ & $(0.48)$ & $(0.33)$ & $(0.42)$ & $(0.35)$ & $(0.43)$ \\
\hline \multirow[t]{2}{*}{ cons } & -0.56 & $-6.17^{\star \star \star}$ & -0.41 & $-5.44^{\star \star \star}$ & $-1.33^{\star \star}$ & $-4.11^{\star \star \star}$ & -0.16 & $-7.90^{\star \star \star}$ & -0.37 & $-7.14^{\star \star \star}$ & -0.69 & $-7.03^{\star \star \star}$ \\
\hline & (0.59) & $(0.98)$ & $(0.55)$ & (1.1) & $(0.65)$ & $(0.79)$ & $(0.69)$ & $(1.28)$ & $(0.58)$ & $(0.99)$ & $(0.7)$ & (1.14) \\
\hline
\end{tabular}


Table 11. (Continued.)

\begin{tabular}{|c|c|c|c|c|c|c|c|c|c|c|c|c|}
\hline \multirow[b]{3}{*}{ Covariates } & \multicolumn{10}{|c|}{ Panel B (Democracy $(C A)$ - Democratic consolidation $(D)$ ) } & & \\
\hline & \multicolumn{2}{|c|}{ polity1 } & \multicolumn{2}{|c|}{ polity 6} & \multicolumn{2}{|c|}{$F H$} & \multicolumn{2}{|c|}{ BMR } & \multicolumn{2}{|c|}{ svmdi50 } & \multicolumn{2}{|c|}{ svmdi75 } \\
\hline & $C A$ & $D$ & $C A$ & D & $C A$ & D & $C A$ & $D$ & $C A$ & D & $C A$ & D \\
\hline \multirow[t]{2}{*}{$L C A(\gamma)$} & $0.81^{\star \star \star}$ & -0.45 & $0.74^{\star \star *}$ & -0.13 & $0.84^{\star \star \star}$ & 0.15 & $0.83^{\star \star \star}$ & -0.40 & $0.78^{\star \star *}$ & -0.30 & $0.56^{\star \star \star}$ & $-0.78^{\star}$ \\
\hline & $(0.11)$ & $(0.33)$ & $(0.12)$ & $(0.35)$ & $(0.1)$ & $(0.24)$ & $(0.12)$ & $(0.38)$ & $(0.11)$ & $(0.28)$ & $(0.13)$ & $(0.32)$ \\
\hline Lloggdp & $-0.40^{\star \star \star}$ & 0.37 & $-0.51^{\star \star \star}$ & $0.50^{\star \star}$ & $-0.36^{\star \star \star}$ & $0.56^{\star \star \star}$ & $-0.53^{\star \star \star}$ & $0.55^{\star}$ & $-0.45^{\star \star \star}$ & $0.44^{\star \star}$ & $-0.59^{\star \star \star}$ & 0.33 \\
\hline \multirow[t]{2}{*}{ Lcrisis } & $0.33^{\star \star \star}$ & $-0.62^{\star \star}$ & $0.23^{\star *}$ & $-0.64^{\star}$ & $0.20^{\star \star}$ & $-0.40^{*}$ & $0.29^{\star \star}$ & $-0.95^{\star \star \star}$ & $0.18^{*}$ & $-0.66^{\star \star \star}$ & $0.22^{*}$ & $-0.67^{\star \star}$ \\
\hline & $(0.11)$ & $(0.3)$ & $(0.12)$ & $(0.33)$ & $(0.1)$ & $(0.21)$ & $(0.12)$ & $(0.34)$ & $(0.11)$ & $(0.25)$ & $(0.13)$ & $(0.29)$ \\
\hline \multirow[t]{2}{*}{ Loil } & $0.44^{\star \star \star}$ & -0.35 & $0.45^{\star \star *}$ & $-0.77^{\star \star \star}$ & $0.40^{\star \star \star}$ & $-0.56^{\star \star}$ & $0.46^{\star \star \star}$ & -0.53 & $0.50^{\star \star \star}$ & 0.16 & $0.34^{\star \star \star}$ & $-0.47^{\star}$ \\
\hline & $(0.11)$ & $(0.32)$ & $(0.11)$ & $(0.22)$ & $(0.1)$ & $(0.25)$ & $(0.1)$ & $(0.34)$ & $(0.1)$ & $(0.47)$ & $(0.11)$ & $(0.28)$ \\
\hline Leduc & 0.05 & 0.13 & $0.10^{\star \star}$ & 0.14 & $0.11^{\star \star \star}$ & 0.07 & $0.09^{*}$ & 0.11 & $0.09^{* *}$ & 0.08 & $0.20^{\star \star \star}$ & $0.19^{\star \star}$ \\
\hline \multirow[t]{2}{*}{ Lethnicfr } & -0.21 & 0.30 & -0.32 & 0.79 & 0.12 & $-0.92^{\star}$ & -0.50 & -0.41 & -0.15 & -0.81 & 0.06 & -0.68 \\
\hline & $(0.3)$ & $(0.65)$ & $(0.33)$ & $(0.76)$ & $(0.29)$ & $(0.48)$ & $(0.34)$ & $(0.83)$ & $(0.3)$ & $(0.58)$ & $(0.41)$ & $(0.68)$ \\
\hline \multirow[t]{2}{*}{ Lreligfr } & 0.35 & 0.75 & 0.08 & -0.23 & 0.16 & 0.21 & 0.16 & 0.38 & -0.25 & 0.35 & $-1.31^{\star \star \star}$ & 0.42 \\
\hline & $(0.31)$ & $(0.6)$ & $(0.32)$ & $(0.74)$ & $(0.26)$ & $(0.41)$ & $(0.32)$ & $(0.75)$ & $(0.31)$ & $(0.53)$ & $(0.41)$ & $(0.64)$ \\
\hline \multirow[t]{2}{*}{ Lregdem } & -0.11 & $2.27^{\star \star \star}$ & -0.09 & $1.44^{\star \star}$ & 0.01 & $3.22^{\star \star \star}$ & -0.08 & $2.58^{\star \star \star}$ & -0.07 & $2.24^{\star \star \star}$ & $0.90^{\star \star *}$ & $2.58^{\star \star \star}$ \\
\hline & $(0.24)$ & $(0.64)$ & $(0.25)$ & $(0.68)$ & $(0.21)$ & $(0.47)$ & $(0.28)$ & $(0.78)$ & $(0.26)$ & $(0.51)$ & $(0.31)$ & $(0.61)$ \\
\hline
\end{tabular}

${ }^{*}$ significant at $10 \%,{ }^{*}$ significant at $5 \%,{ }^{* \star *}$ significant at $1 \%$. 
Table 12. Alternative samples

\begin{tabular}{|c|c|c|c|c|c|c|}
\hline \multicolumn{7}{|c|}{ Panel A (Autocracy $(C A)$ - Emergence of democracy $(D)$ ) } \\
\hline \multirow[b]{2}{*}{ Covariates } & \multicolumn{2}{|c|}{ Balanced } & \multicolumn{2}{|c|}{ No post } & \multicolumn{2}{|c|}{ No split } \\
\hline & $C A$ & $D$ & $C A$ & $D$ & $C A$ & $D$ \\
\hline \multirow[t]{2}{*}{$L C A(\gamma)$} & $1.10^{\star \star \star}$ & $1.39^{\star \star \star}$ & $1.08^{\star \star \star}$ & $1.44^{\star \star \star}$ & $1.11^{\star \star \star}$ & $1.38^{\star \star \star}$ \\
\hline & $(0.19)$ & $(0.35)$ & $(0.12)$ & $(0.26)$ & $(0.13)$ & $(0.26)$ \\
\hline \multirow[t]{2}{*}{$L D(\delta)$} & $2.78^{\star \star}$ & $5.22^{\star \star \star}$ & $2.50^{\star \star \star}$ & $4.20^{\star \star}$ & $1.39^{\star}$ & $3.78^{\star \star}$ \\
\hline & (1.1) & (1.96) & $(0.81)$ & (1.7) & $(0.84)$ & (1.71) \\
\hline \multirow[t]{2}{*}{ Lloggdp } & -0.10 & $0.36^{\star}$ & $-0.18^{\star \star}$ & 0.18 & $-0.39^{\star \star \star}$ & 0.14 \\
\hline & $(0.18)$ & $(0.2)$ & $(0.09)$ & $(0.15)$ & $(0.12)$ & $(0.15)$ \\
\hline \multirow[t]{2}{*}{ Lcrisis } & 0.09 & 0.06 & 0.11 & -0.04 & 0.07 & -0.01 \\
\hline & $(0.13)$ & $(0.25)$ & $(0.11)$ & $(0.23)$ & $(0.11)$ & $(0.23)$ \\
\hline \multirow[t]{2}{*}{ Loil } & $0.23^{*}$ & $-0.88^{\star \star \star}$ & 0.13 & $-1.45^{\star \star \star}$ & $0.34^{\star \star \star}$ & $-0.99^{\star \star \star}$ \\
\hline & $(0.14)$ & $(0.3)$ & $(0.13)$ & $(0.45)$ & $(0.12)$ & $(0.32)$ \\
\hline \multirow[t]{2}{*}{ Leduc } & 0.04 & 0.02 & -0.01 & 0.01 & 0.07 & 0.04 \\
\hline & $(0.26)$ & $(0.08)$ & $(0.06)$ & $(0.06)$ & $(0.1)$ & $(0.07)$ \\
\hline \multirow[t]{2}{*}{ Lurbanpop } & -0.07 & -0.10 & 0.01 & -0.02 & 0.01 & -0.04 \\
\hline & $(0.34)$ & $(0.09)$ & $(0.06)$ & $(0.07)$ & $(0.12)$ & $(0.08)$ \\
\hline \multirow[t]{2}{*}{ Lethnicfr } & 0.87 & -0.00 & 0.38 & -0.18 & 0.87 & 0.01 \\
\hline & $(2.14)$ & $(0.57)$ & $(0.41)$ & $(0.45)$ & $(0.86)$ & $(0.47)$ \\
\hline \multirow[t]{2}{*}{ Lreligfr } & $-0.75^{\star}$ & $-1.06^{\star \star}$ & -0.23 & $-0.82^{\star}$ & -0.07 & -0.74 \\
\hline & $(0.41)$ & $(0.5)$ & $(0.33)$ & $(0.44)$ & $(0.4)$ & $(0.48)$ \\
\hline \multirow[t]{2}{*}{ Lregdem } & 0.45 & $2.66^{\star \star \star}$ & 0.33 & $2.41^{\star \star \star}$ & 0.48 & $2.72^{\star \star \star}$ \\
\hline & $(0.37)$ & $(0.55)$ & $(0.35)$ & $(0.49)$ & $(0.42)$ & $(0.51)$ \\
\hline \multirow[t]{2}{*}{ cons } & -1.19 & $-7.35^{\star \star \star}$ & -0.84 & $-6.31^{\star \star \star}$ & -0.06 & $-6.25^{\star \star \star}$ \\
\hline & $(1.64)$ & $(1.25)$ & $(0.59)$ & $(1.04)$ & $(0.79)$ & $(1.07)$ \\
\hline \multicolumn{7}{|c|}{ Panel B (Democracy $(C A)$ - Democratic consolidation $(D))$} \\
\hline & \multicolumn{2}{|c|}{ Balanced } & \multicolumn{2}{|c|}{ No post } & \multicolumn{2}{|c|}{ No split } \\
\hline Covariates & $C A$ & $D$ & $C A$ & $D$ & $C A$ & $D$ \\
\hline \multirow[t]{2}{*}{$L C A(\gamma)$} & $0.63^{\star \star \star}$ & -0.06 & $0.68^{\star \star \star}$ & -0.03 & $0.65^{\star \star \star}$ & 0.01 \\
\hline & $(0.15)$ & $(0.43)$ & $(0.13)$ & $(0.34)$ & $(0.13)$ & $(0.34)$ \\
\hline \multirow[t]{2}{*}{ Lloggdp } & $-0.68^{\star \star}$ & 0.50 & $-0.73^{\star \star \star}$ & 0.44 & $-0.66^{\star \star \star}$ & $0.52^{\star}$ \\
\hline & $(0.28)$ & $(0.31)$ & $(0.11)$ & $(0.28)$ & $(0.13)$ & $(0.28)$ \\
\hline \multirow[t]{2}{*}{ Lcrisis } & $0.39^{\star \star \star}$ & -0.48 & $0.32^{\star \star \star}$ & $-0.67^{\star \star}$ & $0.33^{\star \star \star}$ & $-0.57^{\star}$ \\
\hline & $(0.15)$ & $(0.36)$ & $(0.12)$ & $(0.31)$ & $(0.13)$ & $(0.31)$ \\
\hline \multirow[t]{2}{*}{ Loil } & $0.46^{\star \star \star}$ & $-0.59^{\star}$ & $0.50^{\star \star \star}$ & 0.31 & $0.47^{\star \star \star}$ & -0.51 \\
\hline & $(0.12)$ & $(0.32)$ & $(0.1)$ & $(0.79)$ & (0.1) & $(0.32)$ \\
\hline
\end{tabular}


Table 12. (Continued.)

\begin{tabular}{|c|c|c|c|c|c|c|}
\hline \multicolumn{7}{|c|}{ Panel B (Democracy $(C A)$ - Democratic consolidation $(D)$ ) } \\
\hline \multirow[b]{2}{*}{ Covariates } & \multicolumn{2}{|c|}{ Balanced } & \multicolumn{2}{|c|}{ No post } & \multicolumn{2}{|c|}{ No split } \\
\hline & $C A$ & $D$ & $C A$ & $D$ & $C A$ & $D$ \\
\hline \multirow[t]{2}{*}{ Leduc } & 0.10 & 0.14 & 0.08 & $0.23^{\star}$ & $0.10^{\star}$ & $0.20^{\star}$ \\
\hline & $(0.11)$ & $(0.13)$ & $(0.05)$ & $(0.12)$ & $(0.06)$ & $(0.12)$ \\
\hline \multirow[t]{2}{*}{ Lurbanpop } & 0.26 & -0.02 & $0.31^{\star \star \star}$ & -0.07 & $0.28^{\star \star *}$ & -0.08 \\
\hline & $(0.21)$ & $(0.15)$ & $(0.07)$ & $(0.13)$ & $(0.09)$ & $(0.13)$ \\
\hline \multirow[t]{2}{*}{ Lethnicfr } & -0.40 & 0.34 & $-0.65^{*}$ & 0.56 & -0.46 & 0.77 \\
\hline & (1.17) & $(0.89)$ & $(0.38)$ & $(0.7)$ & $(0.45)$ & $(0.71)$ \\
\hline \multirow[t]{2}{*}{ Lreligfr } & -0.07 & -0.06 & 0.17 & -0.13 & 0.17 & -0.11 \\
\hline & $(0.6)$ & $(0.76)$ & $(0.35)$ & $(0.66)$ & $(0.37)$ & $(0.67)$ \\
\hline \multirow[t]{2}{*}{ Lregdem } & 0.30 & $2.19^{\star \star \star}$ & 0.35 & $1.81^{\star \star \star}$ & 0.19 & $1.78^{\star \star}$ \\
\hline & $(0.63)$ & $(0.77)$ & (0.39) & (0.69) & $(0.33)$ & $(0.7)$ \\
\hline
\end{tabular}

${ }^{*}$ Significant at $10 \%,{ }^{\star \star}$ significant at $5 \%,{ }^{* \star *}$ significant at $1 \%$.

\subsubsection{Robustness on alternative samples}

Finally, estimations are conducted on three different samples: (1) a balanced panel, which drops countries created after the first year of our sample (5,368 observations, 122 countries, 88 democratizations and 41 reversals $)^{17}$; (2) a no post sample, which excludes countries belonging to the ex-USSR $(6,353$ observations, 155 countries, 111 democratizations, 53 reversals) ${ }^{18}$; a no split sample, which drops all countries that suffered some split (5,900 observations, 136 countries, 106 democratizations, 52 reversals). ${ }^{19}$ Table 12 shows that once again collective action matters for the emergence of democracy but not for its consolidation.

\section{Conclusion}

Many studies analyse the effect of citizens' collective action on democratic change. Generally they employ a bottom-up approach whose focus is on the role of citizens. Nevertheless, although hard to measure, elites' contribution to democratic change is also important, as the top-down approach claims. Our work jointly tests the bottom-up and the top-down approach by introducing a bivariate SDM, which allows us to control for unobserved heterogeneity. The model provides different insights on how collective action and democracy are jointly related in a purely dynamic framework, which builds on the previous literature. In particular, our results show that collective action affects the emergence of democracy but not its consolidation. We also find that collective action is a very persistent state, indicating that once citizens learn how to solve the collective action problem, they are more likely to solve it again in subsequent periods. To the contrary, democratic persistence seems to be very sensitive to which type of democracy indicator is used. Such findings suggest the importance of further investigation on institutional inertia as suggested by many neo-institutionalism scholars.

\footnotetext{
${ }^{17}$ For instance, Suriname and Slovakia are dropped since their independence dates back, respectively, to 1976 and 1993.

${ }^{18}$ These are: Armenia, Azerbaijan, Belarus, Estonia, Georgia, Kazakhstan, Kyrgyzstan, Latvia, Lithuania, Moldova, Tajikistan, Turkmenistan, USSR, Ukraine, Uzbekistan.

${ }^{19}$ We refer to countries belonging to the ex-Yugoslavia, ex-Czechoslovakia, ex-USSR. For the same reason, we also drop Eritrea, Ethiopia, Germany, Sudan, Vietnam, Yemen.
} 
Finally, our results shed light on other determinants of democratic change. In particular, democratizations are more likely when the level of natural resources is lower and the level of democracy in neighbour countries is higher. Instead, democratic consolidations are shaped positively by economic development and negatively by crisis.

Despite the potential advantage of setting an SDM to jointly study changes in countries' level of citizens' collective action and democracy, our approach suffers from some limitations. First, interpreting the effects of unobserved heterogeneity only in terms of elites is not necessarily straightforward, since the latent variable may capture other unobserved factors. Nevertheless, this does not undermine the main result of our work: the role of collective action on the emergence of democracy matters.

Second, our model relies on two main assumptions: local independence and the (discrete) homogeneous autoregressive structure of the latent variable. Nevertheless, the approach can be extended in the future by allowing the discrete latent variable to follow higher order Markov chains. This extension is of interest in this field since democracy can be a long-term memory process, with the role of collective action becoming blurry once a democratic institution has been set.

Finally, spatial econometric issues are unaccounted for and this can limit our results since we are analysing political processes with a high degree of countries' interdependence.

Despite the above limitations, our model paves the way for future empirical research to explore the dynamic of changing preferences and strategies of different political agents in the democratic process by modelling hidden interactions between citizens and elites.

Acknowledgements. We thank the participants of the 2018 Political Economy of Democracy and Dictatorship (Munster), the ECPS 2019 (Jerusalem), the seminars at the Leuphana University, University of Florence and two anonymous reviewers for their valuable comments and suggestions.

\section{References}

Acemoglu, D. and J. A. Robinson (2001), 'A Theory of Political Transitions', American Economic Review, 91(4): 938-963. Acemoglu, D. and J. A. Robinson (2005), Economic Origins of Dictatorship and Democracy, Cambridge, UK: Cambridge University Press.

Acemoglu, D. and J. A. Robinson (2006), 'De Facto Political Power and Institutional Persistence', American Economic Review, 96(2): 325-330.

Acemoglu, D., S. Johnson, J. A. Robinson and P. Yared (2008), 'Income and Democracy', The American Economic Review, 98(3): 808-842.

Acemoglu, D., S. Naidu, P. Restrepo and J. A. Robinson (2019), 'Democracy Does Cause Growth', Journal of Political Economy, 127(1): 47-100.

Aidt, T. S. and R. Franck (2015), 'Democratization Under the Threat of Revolution: Evidence From the Great Reform Act of 1832', Econometrica, 83(2): 505-547.

Aidt, T. S. and G. Leon (2016), 'The Democratic Window of Opportunity: Evidence From Riots in Sub-Saharan Africa', Journal of Conflict Resolution, 60(4): 694-717.

Alemán, J. and D. D. Yang (2011), 'A Duration Analysis of Democratic Transitions and Authoritarian Backslides', Comparative Political Studies, 44(9): 1123-1151.

Alesina, A., A. Devleeschauwer, W. Easterly, S. Kurlat and R. Wacziarg (2003), 'Fractionalization', Journal of Economic Growth, 8(2): 155-194.

Alfonso-Gil, J., M. Lacalle-Calderon and R. aánchez (2014), 'Civil Liberty and Economic Growth in the World: A Long-Run Perspective, 1850-2010', Journal of Institutional Economics, 10(3): 427-449.

Anderson, Christopher J. and A. Paskeviciute (2006), 'How Ethnic and Linguistic Heterogeneity Influence the Prospects for Civil Society: A Comparative Study of Citizenship Behavior', Journal of Politics, 68(4): 783-802.

Ansell, B. and D. Samuels (2010), 'Inequality and Democratization: A Contractarian Approach', Comparative Political Studies, 43(12): 1543-1574.

Banks, A and K. A. Wilson (2016), Cross-National Time-Series Data Archive, Jerusalem: Databanks International, Databanks International, https://www.cntsdata.com/.

Bartolucci, F. and A. Farcomeni (2009), 'A Multivariate Extension of the Dynamic Logit Model for Longitudinal Data Based on A Latent Markov Heterogeneity Structure', Journal of the American Statistical Association, 104(486): 816-831.

Boix, C. (2003), Democracy and Redistribution, Cambridge, UK: Cambridge University Press.

Boix, C., M. Miller and S. Rosato (2013), 'A Complete Data Set of Political Regimes, 1800-2007', Comparative Political Studies, 46(12): 1523-1554.

Brückner, M. and A. Ciccone (2011), 'Rain and the Democratic Window of Opportunity', Econometrica, 79(3): 923-947. 
Burke, P. J. and A. Leigh (2010), 'Do Output Contractions Trigger Democratic Change?', American Economic Journal: Macroeconomics, 2(4): 124-157.

Cheibub, J. A., J. Gandhi and J. R. Vreeland (2010), 'Democracy and Dictatorship Revisited', Public Choice, 143(1): 67-101.

Collier, R. B. (1999), Paths Toward Democracy: The Working Class and Elites in Western Europe and South America, Cambridge, UK: Cambridge University Press.

Collier, P. and A. Hoeffler (2004), 'Greed and Grievance in Civil War', Oxford Economic Papers, 56(4): 563-595.

Dorsch, M. T. and P. Maarek (2019), 'Democratization and the Conditional Dynamics of Income Distribution', American Political Science Review, 113(2): 385-404.

Epstein, D. L., R. Bates, J. Goldstone, I. Kristensen and S. O’Halloran (2006), 'Democratic Transitions', American Journal of Political Science, 50(3): 551-569.

Finkel, S. E. and E. N. Muller (1998), 'Rational Choice and the Dynamics of Collective Political Action: Evaluating Alternative Models with Panel Data', American Political Science Review, 92(1): 37-49.

Gerring, J., M. Hoffman and D. Zarecki (2018), 'The Diverse Effects of Diversity on Democracy', British Journal of Political Science, 48(2): 283-314.

Ghosal, S. and E. Proto (2009), 'Democracy, Collective Action and Intra-Elite conflict', Journal of Public Economics, 93(9-10): 1078-1089.

Gleditsch, K. S. and M. D. Ward (1997), 'Double Take: A Reexamination of Democracy and Autocracy in Modern Polities', Journal of Conflict Resolution, 41(3): 361-383.

Gleditsch, K. S. and M. D. Ward (2006), 'Diffusion and the International Context of Democratization', International Organization, 60(4): 911-933.

Gründler, K. and T. Krieger (2016), 'Democracy and Growth: Evidence From a Machine Learning Indicator', European Journal of Political Economy, 45: 85-107.

Haggard, S. and R. R. Kaufman (2016), Dictators and Democrats: Masses, Elites, and Regime Change, Princeton, NJ: Princeton University Press.

Heckman, J. J. (1981), 'Heterogeneity and State Dependence', in S. Rosen (ed), Studies in Labor Markets, Chicago, IL: University of Chicago Press, pp. 91-140.

Institute for Health Metrics and Evaluation (IHME) (2015), Global Educational Attainment 1970-2015, Seattle, USA. http:// ghdx.healthdata.org/record/global-educational-attainment-1970-2015.

Jack, W. and R. Lagunoff (2006), 'Dynamic Enfranchisement', Journal of Public Economics, 90(4-5): 551-572.

Kingston, C. and G. Caballero (2009), 'Comparing Theories of Institutional Change', Journal of Institutional Economics, 5(2): 151-180.

Laeven, M. L. and M. F. Valencia (2018), Systemic Banking Crises Revisited, IFM Working Paper No. 18/206, International Monetary Fund.

Li Donni, P. and R. Thomas (2019), 'Latent Class Models for Multiple Ordered Categorical Health Data: Testing Violation of the Local Independence Assumption', Empirical Economics, 1-29.

Lipset, S. M. (1959), 'Some Social Requisites of Democracy: Economic Development and Political Legitimacy', American Political Science Review, 53(01): 69-105.

Lizzeri, A. and N. Persico (2004), 'Why did the Elites Extend the Suffrage? Democracy and the Scope of Government, with an Application to Britain's “Age of Reform”, The Quarterly Journal of Economics, 119(2): 707-765.

Marino, M., P. Li Donni, S. Bavetta and M. Cellini (2020), 'The Democratization Process: An Empirical Appraisal of the Role of Political Protest', European Journal of Political Economy, 63: 101881.

Marshall, M., T. Gurr and K. Jaggers (2018), 'Polity iv Project: Political Regime Characteristics and Transitions, 1800-2017', Dataset Users' Manual. Available online: http://www.systemicpeace.org/polity (accessed on 19 October 2018).

North, D. C. (1991), 'Institutions', Journal of Economic Perspectives, 5(1): 97-112.

O’Donnell, G. and P. C. Schmitter (1986), Transitions from Authoritarian Rule: Tentative Conclusions about Uncertain Democracies, Baltimore, MD: Johns Hopkins University Press.

Olson, M. (1965), The Logic of Collective Action, Cambridge, MA: Harvard University Press.

Ostrom, E. (2005), Understanding Institutional Diversity. Princeton, NJ: Princeton University Press.

Papaioannou, E. and G. Siourounis (2008), 'Economic and Social Factors Driving the Third Wave of Democratization', Journal of Comparative Economics, 36(3): 365-387.

Passarelli, F. and G. Tabellini (2017), 'Emotions and Political Unrest', Journal of Political Economy, 125(3): 903-946.

Persson, T. and G. Tabellini (2009), 'Democratic Capital: The Nexus of Political and Economic Change', American Economic Journal: Macroeconomics, 1(2): 88-126.

Przeworski, A., M. Alvarez, J. A. Cheibub and F. Limongi (2000), Democracy and Development: Political Institutions and Well-Being in the World, 1950-1990, Cambridge, UK: Cambridge University Press.

Ross, M. L. (2001), 'Does Oil Hinder Democracy?', World Politics, 53(3): 325-361.

Ross, M and P. Mahdavi (2015), Oil and Gas Data, 1932-2014, Harvard Dataverse http://dx.doi.org/10.7910/DVN/ZTPW0Y.

Rüdig, W. and G. Karyotis (2014), 'Who Protests in Greece? Mass Opposition to Austerity', British Journal of Political Science, 44(3): 487-513. 
Starr, H. (1991), 'Democratic Dominoes: Diffusion Approaches to the Spread of Democracy in the International System', Journal of Conflict Resolution, 35(2): 356-381.

Teorell, J. (2010), Determinants of Democratization: Explaining Regime Change in the World, 1972-2006, Cambridge, UK: Cambridge University Press.

Thyne, C. L. (2006), 'Abc's, 123's, and the Golden Rule: The Pacifying Effect of Education on Civil War, 1980-1999', International Studies Quarterly, 50(4): 733-754.

Tylecote, A. (2016), 'Institutions Matter: But Which Institutions? and How and Why Do They Change?', Journal of Institutional Economics, 12(3): 721-742.

UN Statistics (2016), National Accounts Main Aggregates Database, United Nation. https://unstats.un.org/unsd/snaama/dnlList.asp.

Wooldridge, J. M. (2005), 'Simple Solutions to the Initial Conditions Problem in Dynamic, Nonlinear Panel Data Models with Unobserved Heterogeneity', Journal of Applied Econometrics, 20(1): 39-54.

World Bank Group (2012), World Development Indicators 2012, World Bank. http://documents.worldbank.org/curated/en/ 553131468163740875/World-development-indicators-2012, Washington, DC.

Cite this article: Li Donni P, Marino M (2020). The role of collective action for the emergence and consolidation of democracy. Journal of Institutional Economics 16, 831-862. https://doi.org/10.1017/S1744137420000247 


\section{Appendix}

\section{Appendix A. Model estimation}

The Structural Dynamic Model (SDM) described by the system of equations (1) relies on two sets of parameters:

(1) the conditional distribution of $D_{i t}$ and $C A_{i t}$ :

$$
\begin{array}{ll}
\operatorname{Pr}\left(C A_{i t}=1 \mid \alpha, \boldsymbol{x}_{i t-1}, D_{i t-1}, C A_{i t-1}\right) & =\Lambda\left(\alpha_{c a i t}(c)+\boldsymbol{x}_{i t-1}^{\prime} \boldsymbol{\beta}_{c a}+D_{i, t-1} \delta_{c a}+C A_{i t-1} \gamma_{c a}\right) \\
\operatorname{Pr}\left(D_{i t}=1 \mid \alpha, \boldsymbol{x}_{i t-1}, D_{i t-1}, C A_{i t-1}\right) & =\Lambda\left(\alpha_{d i t}(c)+\boldsymbol{x}_{i t-1}^{\prime} \boldsymbol{\beta}_{d}+D_{i, t-1} \delta_{d}+C A_{i t-1} \gamma_{d}\right)
\end{array}
$$

where $\Lambda$ is the logit link function; $\alpha_{d i t}$ and $\alpha_{\text {cait }}$ are the random individual specific terms, one for each latent state $c$, and capture the effect of the unobservable latent state $U(c)$ on $D_{i t}$ and $C A_{i t}$ (the arrows from $U$ to $D$ and $C A$ in Figure 1). Finally $\gamma_{c a}$ and $\delta_{d}$ capture the persistence respectively on $C A$ and $D$, while $\gamma_{d}$ and $\delta_{c a}$ the crossed effects of $D$ and $C A$ respectively on $C A$ and $D$.

(2) the distribution of the subject-specific parameters $\alpha$ s, capturing the unobservable heterogeneity, is described by the initial probabilities and the transition probabilities. In particular for each country $i$, initial probabilities are described by $p\left(\boldsymbol{\alpha}_{i 1}=\boldsymbol{c} \mid D_{i 0}, C A_{i 0}, \boldsymbol{x}_{i 0}\right)$, where $\boldsymbol{\alpha}_{i 1}=\left[\alpha_{d i 1}, \alpha_{c a i 1}\right]$. To take into account the initial condition problem (Heckman, 1981), these probabilities are allowed to depend on the initial observations $D_{i 0}, C A_{i 0}, x_{i 0}$ using a multinomial logit parametrization. Finally, transition probabilities are denoted by $\pi_{c j}=p\left(\boldsymbol{\alpha}_{i t}=j \mid \alpha_{i t-1}=c\right)$, with $c, j=1, \ldots, k$ and $t=$ $2, \ldots, T$. They are collected in $k \times k$ matrix $\boldsymbol{\Pi}$. Note that transition probabilities only depend on the previous time period given the first-order assumption on the Markov chain. These probabilities are of particular interest as they describe how countries move between unobserved states.

The estimation of the above parameters can be implemented by following Bartolucci and Farcomeni (2009), but extending their case to unbalanced panel. In practice, the estimation strategy relies on a family of multivariate link functions that allow to directly model (i) the marginal distribution of $D$ and $C A$, (ii) their association, and (iii) the distribution of the subject-specific parameters. Let $v_{d i t}$ and $v_{\text {cait }}$ be independent error terms with standard logistic distribution, then the system of equation (1) can be rewritten to describe the marginal distribution of $D$ and $C A$ as follows:

$$
\begin{aligned}
& \log \frac{p\left(D_{i t}=1 \mid \alpha, \boldsymbol{x}_{i t-1}, D_{i, t-1}, C A_{i, t-1}\right)}{p\left(D_{i t}=0 \mid \alpha, \boldsymbol{x}_{i t-1}, D_{i, t-1}, C A_{i, t-1}\right)}=\alpha_{d i t}(c)+\boldsymbol{x}_{i t-1}^{\prime} \boldsymbol{\beta}+D_{i, t-1} \delta_{d}+C A_{i t-1} \gamma_{d} \\
& \log \frac{p\left(C A_{i t}=1 \mid \alpha, \boldsymbol{x}_{i t-1}, D_{i, t-1}, C A_{i, t-1}\right)}{p\left(C A_{i t}=0 \mid \alpha, \boldsymbol{x}_{i t-1}, D_{i, t-1}, C A_{i, t-1}\right)}=\alpha_{c a i t}(c)+\boldsymbol{x}_{i t-1}^{\prime} \boldsymbol{\beta}+D_{i, t-1} \delta_{c a}+C A_{i t-1} \gamma_{c a}
\end{aligned}
$$

The residual association between $D_{i t}$ and $C A_{i t}, \rho$, is modelled by including the marginal log-odds ratio defined as the contrast between the two variables:

$$
\log \left[\frac{p\left(D_{i t}=0, C A_{i t}=0 \mid \alpha, \boldsymbol{x}_{i t-1}, D_{i, t-1}, C A_{i, t-1}\right) p\left(D_{i t}=1, C A_{i t}=1 \mid \alpha, \boldsymbol{x}_{i t-1}, D_{i, t-1}, C A_{i, t-1}\right)}{p\left(D_{i t}=0, C A_{i t}=1 \mid \alpha, \boldsymbol{x}_{i t-1}, D_{i, t-1}, C A_{i, t-1}\right) p\left(D_{i t}=1, C A_{i t}=0 \mid \alpha, \boldsymbol{x}_{i t-1}, D_{i, t-1}, C A_{i, t-1}\right)}\right]=\rho
$$

$\rho$ captures any current residual association between collective action and democracy which still remains after conditioning on $\boldsymbol{x}_{t-1}$, lagged dependent variables and unobservable $U$.

Finally, for each country $i$, the random parameter vector $\boldsymbol{\alpha}_{i t}=\left[\alpha_{\text {dit }}, \alpha_{\text {cait }}\right]$ is assumed to follow a first-order Markov chain with states $c$, for $c=1, \ldots, k$. Initial probabilities are allowed to depend on the initial observation using a multinomial logit parametrization as follows:

$$
\begin{aligned}
p\left(\boldsymbol{\alpha}_{i 1}\right. & \left.=c \mid D_{i 0}, C A_{i 0}, \boldsymbol{x}_{i 0}\right) \\
& =\frac{\exp \left(\alpha_{0}^{c}+\boldsymbol{x}_{i 0}^{\prime} \beta_{c}+\gamma_{c} C A_{i 0}+\delta_{c} D_{i 0}\right.}{1+\sum_{c=2}^{k} \exp \left(\alpha_{0}^{c}+\boldsymbol{x}_{i 0}^{\prime} \beta_{c}+\gamma_{c} C A_{i 0}+\delta_{c} D_{i 0}\right.} \quad \text { with } c=2, \ldots, k .
\end{aligned}
$$

Finally, the transition probabilities are denoted by $\pi_{c j}=p\left(\boldsymbol{\alpha}_{i t}=j \mid \alpha_{i t-1}=c\right), c, j=1, \ldots, k, t=2, \ldots, T$ and are collected in the $k \times$ $k$ matrix $\boldsymbol{\Pi}$. Note that transition probabilities only depend on the previous time period given the Markov chain first-order assumption. These probabilities describe how unobservable factors in $c$ evolve over time capturing time variation on $H_{i t}$.

The system of equations (2)-(5) and the transition probabilities $\pi_{c j}$ are estimated via EM algorithm. 


\section{Appendix B. List of countries}

\begin{tabular}{|c|c|c|c|c|c|c|c|c|}
\hline Country & First & Last & Country & First & Last & Country & First & Last \\
\hline Afghanistan & 1971 & 2014 & Germany & 1991 & 2014 & Norway & 1971 & 2014 \\
\hline Albania & 1971 & 2014 & Germany, East & 1971 & 1990 & Oman & 1974 & 2014 \\
\hline Algeria & 1971 & 2014 & Germany, West & 1971 & 1990 & Pakistan & 1971 & 2014 \\
\hline Angola & 1976 & 2014 & Ghana & 1971 & 2014 & Panama & 1971 & 2014 \\
\hline Argentina & 1971 & 2014 & Greece & 1971 & 2014 & Papua New Guinea & 1977 & 2014 \\
\hline Armenia & 1992 & 2014 & Guatemala & 1971 & 2014 & Paraguay & 1971 & 2014 \\
\hline Australia & 1971 & 2014 & Guinea & 1971 & 2014 & Peru & 1971 & 2014 \\
\hline Austria & 1971 & 2014 & Guinea-Bissau & 1975 & 2014 & Philippines & 1971 & 2014 \\
\hline Azerbaijan & 1992 & 2014 & Guyana & 1971 & 2014 & Poland & 1971 & 2014 \\
\hline Bahrain & 1972 & 2014 & Haiti & 1971 & 2014 & Portugal & 1971 & 2014 \\
\hline Bangladesh & 1972 & 2014 & Honduras & 1971 & 2014 & Qatar & 1972 & 2014 \\
\hline Belarus & 1992 & 2014 & Hungary & 1971 & 2014 & Romania & 1971 & 2014 \\
\hline Belgium & 1971 & 2014 & India & 1971 & 2014 & Rwanda & 1971 & 2014 \\
\hline Benin & 1971 & 2014 & Indonesia & 1971 & 2014 & Saudi Arabia & 1971 & 2014 \\
\hline Bhutan & 1972 & 2014 & Iran & 1971 & 2014 & Senegal & 1971 & 2014 \\
\hline Bolivia & 1971 & 2014 & Iraq & 1971 & 2014 & Sierra Leone & 1971 & 2014 \\
\hline Bosnia and Herzegovina & 1992 & 2014 & Ireland & 1971 & 2014 & Singapore & 1971 & 2014 \\
\hline Botswana & 1971 & 2014 & Israel & 1971 & 2014 & Slovakia & 1993 & 2014 \\
\hline Brazil & 1971 & 2014 & Italy & 1971 & 2014 & Slovenia & 1991 & 2014 \\
\hline Bulgaria & 1971 & 2014 & Jamaica & 1971 & 2014 & Solomon Islands & 1979 & 2014 \\
\hline Burkina Faso & 1971 & 2014 & Japan & 1971 & 2014 & Somalia & 1971 & 2014 \\
\hline Burundi & 1971 & 2014 & Jordan & 1971 & 2014 & South Africa & 1971 & 2014 \\
\hline Cambodia & 1975 & 2014 & Kazakhstan & 1992 & 2014 & Spain & 1971 & 2014 \\
\hline Cameroon & 1971 & 2014 & Kenya & 1971 & 2014 & Sri Lanka & 1971 & 2014 \\
\hline
\end{tabular}


Appendix B. (Continued.)

\begin{tabular}{|c|c|c|c|c|c|c|c|c|}
\hline Country & First & Last & Country & First & Last & Country & First & Last \\
\hline Canada & 1971 & 2014 & Korea, North & 1971 & 2014 & Sudan & 1971 & 2014 \\
\hline Cape Verde & 1976 & 2014 & Korea, South & 1971 & 2014 & Suriname & 1976 & 2014 \\
\hline Central African Republic & 1971 & 2014 & Kuwait & 1971 & 2014 & Swaziland & 1971 & 2014 \\
\hline Chad & 1971 & 2014 & Kyrgyzstan & 1992 & 2014 & Sweden & 1971 & 2014 \\
\hline Chile & 1971 & 2014 & Laos & 1971 & 2014 & Switzerland & 1971 & 2014 \\
\hline China & 1971 & 2014 & Latvia & 1992 & 2014 & Syria & 1971 & 2014 \\
\hline Colombia & 1971 & 2014 & Lebanon & 1971 & 2014 & Taiwan & 1971 & 2014 \\
\hline Comoros & 1976 & 2014 & Lesotho & 1971 & 2014 & Tajikistan & 1992 & 2014 \\
\hline Congo & 1971 & 2014 & Liberia & 1971 & 2014 & Tanzania & 1971 & 2014 \\
\hline Congo, Democratic Republic & 1971 & 2014 & Libya & 1971 & 2014 & Thailand & 1971 & 2014 \\
\hline Costa Rica & 1971 & 2014 & Lithuania & 1992 & 2014 & Togo & 1971 & 2014 \\
\hline Cote d'Ivoire & 1971 & 2014 & Luxembourg & 1971 & 2014 & Trinidad and Tobago & 1971 & 2014 \\
\hline Croatia & 1992 & 2014 & Macedonia & 1993 & 2014 & Tunisia & 1971 & 2014 \\
\hline Cuba & 1971 & 2014 & Madagascar & 1975 & 2014 & Turkey & 1971 & 2014 \\
\hline Cyprus & 1971 & 2014 & Malawi & 1971 & 2014 & Turkmenistan & 1992 & 2014 \\
\hline Czech Republic & 1993 & 2014 & Malaysia & 1971 & 2014 & Uganda & 1971 & 2014 \\
\hline Czechoslovakia & 1971 & 1992 & Mali & 1971 & 2014 & Ukraine & 1992 & 2014 \\
\hline Denmark & 1971 & 2014 & Mauritania & 1971 & 2014 & United Arab Emirates & 1972 & 2014 \\
\hline Djibouti & 1978 & 2014 & Mauritius & 1971 & 2014 & United Kingdom & 1971 & 2014 \\
\hline Dominican Republic & 1971 & 2014 & Mexico & 1971 & 2014 & United States & 1971 & 2014 \\
\hline Ecuador & 1971 & 2014 & Moldova & 1992 & 2014 & Uruguay & 1971 & 2014 \\
\hline Egypt & 1971 & 2014 & Mongolia & 1971 & 2014 & USSR and Russia & 1971 & 2014 \\
\hline El Salvador & 1971 & 2014 & Montenegro & 2006 & 2014 & Uzbekistan & 1992 & 2014 \\
\hline Equatorial Guinea & 1971 & 2014 & Morocco & 1971 & 2014 & Venezuela & 1971 & 2014 \\
\hline
\end{tabular}




\begin{tabular}{|c|c|c|c|c|c|c|c|c|}
\hline Eritrea & 1993 & 2014 & Mozambique & 1975 & 2014 & Vietnam & 1971 & 2014 \\
\hline Estonia & 1992 & 2014 & Myanmar & 1971 & 2014 & Vietnam, South & 1971 & 1975 \\
\hline Ethiopia & 1971 & 2014 & Namibia & 1990 & 2014 & Yemen & 1990 & 2014 \\
\hline Fiji & 1971 & 2014 & Nepal & 1971 & 2014 & Yemen, North & 1971 & 1989 \\
\hline Finland & 1971 & 2014 & Netherlands & 1971 & 2014 & Yemen, South & 1971 & 1989 \\
\hline France & 1971 & 2014 & New Zealand & 1971 & 2014 & Yug. and ex Yug. & 1971 & 2014 \\
\hline Gabon & 1971 & 2014 & Nicaragua & 1971 & 2014 & Zambia & 1971 & 2014 \\
\hline Gambia & 1971 & 2014 & Niger & 1971 & 2014 & Zimbabwe & 1971 & 2014 \\
\hline Georgia & 1992 & 2014 & Nigeria & 1971 & 2014 & & & \\
\hline
\end{tabular}




\section{Appendix C. Initial conditions}

In the spirit of the Heckman's initial condition problem, the SDM allows the unobservable latent states to depend on the countries' initial observation. In practice, the estimated parameters can be interpreted as the effect of an observable characteristic on the probability of being in a specific latent state with respect to another state at the initial period. Parameters are reported in Table $\mathrm{C} 1$. Since there are only two latent states, coefficients can be interpreted as the contribution of a specific covariate on the probability of being in the second latent state with respect to the first latent state.

Two results are noteworthy. First, a country experiencing collective action in the first period is more likely than a country without collective action to belong to the second state, namely to those countries where democracy comes with more political mobilizations. In other words, once citizens have historically developed the formal and informal framework to solve the collective action problem, then it is easier for them to be mobilized again. Second, a country with a higher level of ethnic fractionalization in the first period is more likely to belong to the first state, where democracy comes with less political mobilizations and more top-down reforms. This result confirms recent findings that diversity is not necessarily detrimental to democracy (Gerring et al., 2018). However, our model shows that diversity affects the initial stock of social capital within a society (Anderson and Paskeviciute, 2006).

Table C1. Estimated coefficients of the initial conditions

\begin{tabular}{ccccccccccccc}
\hline Type & cons & $C A$ & $D$ & loggdp & crisis & oil & educ & urbanpop & ethnicfr & religfr & regdem \\
\hline 2 vs 1 & 2,32 & $3,62^{\star \star \star}$ & 0,30 & $-0,15$ & 1,10 & $-2,25$ & $-0,32^{\star}$ & 0,14 & $-4,95^{\star \star \star}$ & 0,80 & $-2,17$ \\
\hline & $(2,29)$ & $(0,92)$ & $(0,44)$ & $(1,56)$ & $(4,82)$ & $(0,19)$ & $(0,24)$ & $(1,72)$ & $(1,72)$ & $(1,56)$ & $(1,63)$ \\
\hline
\end{tabular}

${ }^{*}$ significant at $10 \%,{ }^{* *}$ significant at $5 \%,{ }^{* * *}$ significant at $1 \%$. 


\section{Appendix D. Robustness model selection}

\begin{tabular}{|c|c|c|c|c|c|c|c|c|c|}
\hline Model & k & $\mathrm{BIC}$ & lk & \#par & Model & $k$ & $\mathrm{BIC}$ & lk & \#par \\
\hline int2 & 1 & $7,585.89$ & $-3,471.96$ & 125 & polity6 & 1 & $8,849.70$ & $-4,103.86$ & 125 \\
\hline int2 & 2 & $7,277.44$ & $-3,279.22$ & 140 & polity6 & 2 & $8,461.21$ & $-3,871.10$ & 140 \\
\hline int2 & 3 & $7,295.92$ & $-3,244.80$ & 157 & polity6 & 3 & $8,482.39$ & $-3,838.03$ & 157 \\
\hline int3 & 1 & $6,472.60$ & $-2,915.31$ & 125 & fh & 1 & $9,085.77$ & $-4,232.17$ & 121 \\
\hline int3 & 2 & $6,220.31$ & $-2,750.65$ & 140 & fh & 2 & $8,735.28$ & $-4,018.40$ & 136 \\
\hline int3 & 3 & $6,227.41$ & $-2,710.54$ & 157 & fh & 3 & $8,762.12$ & $-3,988.17$ & 153 \\
\hline antigov & 1 & $7,893.66$ & $-3,625.84$ & 125 & boix & 1 & $8,696.23$ & $-4,027.13$ & 125 \\
\hline antigov & 2 & $7,602.02$ & $-3,462.05$ & 132 & boix & 2 & $8,297.11$ & $-3,789.05$ & 140 \\
\hline antigov & 3 & $7,569.25$ & $-3,422.55$ & 141 & boix & 3 & $8,316.33$ & $-3,755.00$ & 157 \\
\hline antigov & 4 & $7,599.90$ & $-3,409.63$ & 152 & svmdi50 & 1 & $9,223.38$ & $-4,290.70$ & 125 \\
\hline strikes & 1 & $5,064.50$ & $-2,211.26$ & 125 & svmdi50 & 2 & $8,842.02$ & $-4,061.50$ & 140 \\
\hline strikes & 2 & $4,882.45$ & $-2,102.26$ & 132 & svmdi50 & 3 & $8,867.50$ & $-4,030.59$ & 157 \\
\hline strikes & 3 & $4,874.30$ & $-2,075.08$ & 141 & svmdi75 & 1 & $9,037.78$ & $-4,197.90$ & 125 \\
\hline strikes & 4 & $4,911.53$ & $-2,065.44$ & 152 & svmdi75 & 2 & $8,647.25$ & $-3,964.12$ & 140 \\
\hline riots & 1 & $6,892.63$ & $-3,125.33$ & 125 & svmdi75 & 3 & $8,629.52$ & $-3,911.60$ & 157 \\
\hline riots & 2 & $6,666.25$ & $-2,994.16$ & 132 & svmdi75 & 4 & $8,688.77$ & $-3,892.43$ & 176 \\
\hline riots & 3 & $6,671.84$ & $-2,973.85$ & 141 & balance & 1 & $7,313.81$ & $-3,356.65$ & 125 \\
\hline revolution & 1 & $5,907.15$ & $-2,632.59$ & 125 & balance & 2 & $6,990.37$ & $-3,158.90$ & 140 \\
\hline revolution & 2 & $5,741.09$ & $-2,531.58$ & 132 & balance & 3 & $7,022.39$ & $-3,134.08$ & 157 \\
\hline revolution & 3 & $5,747.23$ & $-2,511.54$ & 141 & no postsov & 1 & $8,519.73$ & $-3,944.65$ & 125 \\
\hline scad & 1 & $1,752.42$ & -705.17 & 87 & no postsov & 2 & $8,140.11$ & $-3,717.01$ & 140 \\
\hline scad & 2 & $1,707.14$ & -653.05 & 102 & no postsov & 3 & $8,175.69$ & $-3,691.94$ & 157 \\
\hline scad & 3 & $1,717.86$ & -624.99 & 119 & split & 1 & $8,013.22$ & $-3,699.57$ & 125 \\
\hline polity1 & 1 & $8,984.46$ & $-4,171.24$ & 125 & split & 2 & $7,681.27$ & $-3,496.75$ & 140 \\
\hline polity1 & 2 & $8,603.47$ & $-3,942.23$ & 140 & split & 3 & $7,722.25$ & $-3,475.48$ & 157 \\
\hline polity1 & 3 & $8,606.41$ & $-3,900.05$ & 157 & & & & & \\
\hline
\end{tabular}




\begin{tabular}{|c|c|c|c|c|c|c|c|c|c|c|c|c|c|c|c|c|c|c|c|c|c|}
\hline \multicolumn{4}{|c|}{ int2 } & \multicolumn{4}{|c|}{ int3 } & \multicolumn{5}{|c|}{ antigov } & \multicolumn{5}{|c|}{ strikes } & \multicolumn{4}{|c|}{ riots } \\
\hline & 1 & 2 & $\hat{\mathrm{N}}$ & & 1 & 2 & $\hat{N}$ & & 1 & 2 & 3 & $\hat{\mathrm{N}}$ & & 1 & 2 & 3 & $\hat{\mathrm{N}}$ & & 1 & 2 & $\hat{\mathrm{N}}$ \\
\hline 1 & 0.9949 & 0.0051 & 114 & 1 & 0.9963 & 0.0037 & 112 & 1 & 0.9442 & 0.0558 & 0 & 58 & 1 & 0.9711 & 0.0234 & 0.0055 & 67 & 1 & 0.9894 & 0.0106 & 111 \\
\hline 2 & 0.0086 & 0.9914 & 56 & 2 & 0.0093 & 0.9907 & 58 & 2 & 0 & 0.9791 & 0.0209 & 83 & 2 & 0.0036 & 0.9919 & 0.0045 & 75 & 2 & 0.0061 & 0.9939 & 59 \\
\hline 3 & $\mathrm{n} / \mathrm{a}$ & $\mathrm{n} / \mathrm{a}$ & $\mathrm{n} / \mathrm{a}$ & 3 & $\mathrm{n} / \mathrm{a}$ & $\mathrm{n} / \mathrm{a}$ & $\mathrm{n} / \mathrm{a}$ & 3 & 0 & 0.0113 & 0.9887 & 29 & 3 & 0 & 0.0135 & 0.9865 & 28 & 3 & $\mathrm{n} / \mathrm{a}$ & $\mathrm{n} / \mathrm{a}$ & $n / a$ \\
\hline \multicolumn{4}{|c|}{ revolution } & \multicolumn{4}{|c|}{ scad } & \multicolumn{5}{|c|}{ polity1 } & \multicolumn{5}{|c|}{ polity6 } & \multicolumn{4}{|c|}{ fh } \\
\hline & 1 & 2 & $\hat{\mathrm{N}}$ & & 1 & 2 & $\hat{\mathrm{N}}$ & & 1 & 2 & 3 & $\hat{\mathrm{N}}$ & & 1 & 2 & 3 & $\hat{\mathrm{N}}$ & & 1 & 2 & $\hat{\mathrm{N}}$ \\
\hline 1 & 0.9855 & 0.0145 & 133 & 1 & 0.9497 & 0.0503 & 18 & 1 & 0.9798 & 0.0202 & $\mathrm{n} / \mathrm{a}$ & 108 & 1 & 0.9825 & 0.0175 & $\mathrm{n} / \mathrm{a}$ & 110 & 1 & 0.9819 & 0.0181 & 110 \\
\hline 2 & 0.0453 & 0.9547 & 37 & 2 & 0.0065 & 0.9935 & 33 & 2 & 0.0233 & 0.9767 & $\mathrm{n} / \mathrm{a}$ & 62 & 2 & 0.0216 & 0.9784 & $\mathrm{n} / \mathrm{a}$ & 60 & 2 & 0.0203 & 0.9797 & 59 \\
\hline \multicolumn{4}{|c|}{ boix } & \multicolumn{4}{|c|}{ svmdi50 } & \multicolumn{5}{|c|}{ svmdi75 } & \multicolumn{5}{|c|}{ balance } & \multicolumn{4}{|c|}{ no post } \\
\hline & 1 & 2 & $\hat{\mathrm{N}}$ & & 1 & 2 & $\hat{\mathrm{N}}$ & & 1 & 2 & 3 & $\hat{\mathrm{N}}$ & & 1 & 2 & 3 & $\hat{\mathrm{N}}$ & & 1 & 2 & $\hat{\mathrm{N}}$ \\
\hline 1 & 0.9826 & 0.0174 & 112 & 1 & 0.9814 & 0.0186 & 110 & 1 & 0.9779 & 0.0221 & 0 & 53 & 1 & 0.9838 & 0.0162 & $\mathrm{n} / \mathrm{a}$ & 77 & 1 & 0.9828 & 0.0172 & 100 \\
\hline 2 & 0.0223 & 0.9777 & 58 & 2 & 0.0247 & 0.9753 & 60 & 2 & 0.0004 & 0.9712 & 0.0284 & 76 & 2 & 0.0262 & 0.9738 & $\mathrm{n} / \mathrm{a}$ & 45 & 2 & 0.029 & 0.971 & 55 \\
\hline 3 & $\mathrm{n} / \mathrm{a}$ & $\mathrm{n} / \mathrm{a}$ & $\mathrm{n} / \mathrm{a}$ & 3 & $\mathrm{n} / \mathrm{a}$ & $\mathrm{n} / \mathrm{a}$ & $\mathrm{n} / \mathrm{a}$ & 3 & 0.0066 & 0.0407 & 0.9527 & 41 & 3 & $\mathrm{n} / \mathrm{a}$ & $\mathrm{n} / \mathrm{a}$ & $\mathrm{n} / \mathrm{a}$ & $\mathrm{n} / \mathrm{a}$ & 3 & $\mathrm{n} / \mathrm{a}$ & $\mathrm{n} / \mathrm{a}$ & $\mathrm{n} / \mathrm{a}$ \\
\hline \multicolumn{4}{|c|}{ no split } & & & & & & & & & & & & & & & & & & \\
\hline & 1 & 2 & $\hat{\mathrm{N}}$ & & & & & & & & & & & & & & & & & & \\
\hline 1 & 0.9827 & 0.0173 & 88 & & & & & & & & & & & & & & & & & & \\
\hline 2 & 0.0273 & 0.9727 & 48 & & & & & & & & & & & & & & & & & & \\
\hline
\end{tabular}

